\title{
MAMMALS COLLECTED BY DR. W. L. ABBOTT ON THE COAST AND ISLANDS OF NORTHWEST SUMATRA.
}

\author{
By Gerrit S. Miller, Jr. \\ Assistant Curator, Division of Mammals.
}

The period from November, 1901, to April, 1902, was spent by Dr. W. L. Abbott in exploration of the coast and islands of northwestern Sumatra. As a result of this work large and exceedingly valuable collections were obtained, all of which have been presented to the United States National Museum. This paper contains an account of the mammals, numbering 492 specimens.

\section{ITINERARY AND DESCRIPTION OF LOCALITIES.}

Leaving Singapore about the middle of October, Dr. Abbott sailed northwarc through the Strait of Malacea. His first collecting station was at Loh Sidoh Bay, on the west coast of Sumatra, a few miles south of Acheen Head, the extreme northwestern point of the island. Only four days, November 5 to 8 , were spent at this locality, which, to judge by the remarks in the collector's field book, is a moderately hilly region abounding in dense jungle and in cocoanut plantations. Dr. Abbott says of this locality:

It was probably a pretty good place for collecting, but one dare not go far off, and the natives stole my traps. There was a Dutch patrol there, but the sergeant in charge said it was anything but safe.

The next locality visited was the large island forming the northern end of the archipelago off the west coast of Sumatra. It is variously known as Pulo Simalur, Pulo Simaloe, Pulo Si Malu, Pulo Babie, and Hog Island. The first of these names is the one adopted by Dr. Abbott. This island is about 55 miles in length and is moderately high and hilly. Its surface is well wooded. Here about six weeks (November 16, 1901, to January 2, 1902) were spent. Mammals were collected at several localities on the island: Telok Dalam, at about middle of east coast (November 18 to 28); Sibabo Bay, a short distance north of Telok Dalam (December 10 to 17); Sigoeli River, near north end of island (December 19); Pulo Siumat (December 27 to 30), and Labuan Badjan Bay (January 1, 1902), at southern extremity. Pulo 
Siumat lies about 5 miles off the eastern coast of Simalur, about halfway between Telok Dalam and Labuan Badjan Bay. It contains about 1,000 acres and is mostly cleared and planted with cocoanuts, etc.

Two small islands, the Tapak or Flat Islands, about 15 miles from the southeastern extremity of Simalur, were next explored (January 4 to 9). Pulo Lasia (pronounced Lahseea), the more northerly and also the smaller, is an uninhabited mass of coral rock covered with dense forest. It is about $2 \frac{1}{2}$ miles long and 2 miles wide. Separated from Pulo Lasia by a strait a mile and a half wide is Pulo Babi, a slightly larger island, also of coral rock, but with more sand and soil than there is on Lasia. Like the smaller island, it is uninhabited, though the forest contains some cocoanut palms, and pigs are very abundant.

Nineteen miles east of Pulo Babi and 31 miles north of Nias lies Pulo Bangkaru, the most westerly and second largest of the Banjak or Banyak (many) Islands, the group next visited (January 16 to February 6). The surface is irregular and heavily forested, its highest point probably rising 1,000 feet above the sea. The island covers an area of about 20 square miles. A week was spent here at an anchorage in Cameleon Bay on the southeast coast. Great Banjak Island, Pulo Tuangku, or Tunanku (spelled Toeankoe on the Dutch charts), is 6 miles east of Pulo Bangkaru and 25 from Singkel, the nearest point in Sumatra. It is about 17 miles long by 5 wide and probably contains 40 or 50 square miles. The highest points are Bukit Teressa, a coneshaped hill about 1,009 feet in altitude, and Batu Lauteh, which rises to about 800 feet. Both are situated at the north end of the island, where are also the few clearings and paddy fields. Cultivation on any extended scale is prevented by the abundance of pigs and monkeys, but on the islets off the coast cocoanuts are successfully grown.

From the Banjak Islands Dr. Abbott crossed to Tapanuli (or Tappanoeli) Bay on the west coast of Sumatra. Here he spent the last half of February and the month of March, partly at points on the mainland and partly (March 2 to 14) at Pulo Mansalar (also spelled Moesalla, Massalla, Mansalla, and Mensilla), at the entrance to the bay. The principal collecting stations were Tapanuli and Siboga settlements, near the north end of the bay, Jaga Jaga, a stream near the south end, Butik Kebong and Butik Sawa, hills 1,224 and 1,100 feet in height, respectively, lying near the coast just south of the Jaga Jaga, Lobo Pandan Bay, at the south foot of Butik Kebong, and Gumong Panjamurong Udong, a hill on the south side of Lobo Pandan Bay. The country throughout this region is fertile and well forested. Pulo Mansalar, at the mouth of Tapanuli Bay, is 7 miles from the mainland. It is 11 miles long and contains 45 square miles. The heavily forested surface is mountainous, with scarcely any level ground, though the highest point is only 1,660 feet above sea level. The timber is very fine, and much is cut and taken to Siboga for house building. 
SYSTEMATIC LIST OF SPECIES.

\section{FAMILY TRAGULID A.}

TRAGULUS NAPU (F. Cuvier).

1822. Moschus napu F. Cuvier, Hist. Nat. des Mammiféres, IV, Pt. 37, [p. 108], November, 1822; Sumatra.

An adult male and three immature specimens were taken at Tapanuli Bay. (For measurements see table, page 442.) These are the first representatives of the species received by the United States National Museum. In all respects they agree with those recently recorded by Stone and Rehn ${ }^{a}$ from the Lampong district. ${ }^{b}$ Tragulus napu proves to be a grayish animal quite distinct from $T$. pretiosus and T. nigricollis, but somewhat closely resembling $T$. canescens of the Malay Peninsula. The general appearance is well indicated by the larger figure on Cuvier's plate.

TRAGULUS AMENUS, new species.

Type--Adult male (skin and skull), Cat. No. 114563, U.S.N.M. Collected on Pulo Mansalar, off Tapanuli Bay, Sumatra, March 8, 1902, by Dr. W. L. Abbott. Original number, 1632.

Characters.-A yellowish, dark-necked member of the napu group, somewhat closely resembling Tragulus nigricollis ${ }^{c}$ of Sinkep Island, but smaller and more richly colored. Throat pattern normal, the dark stripes blackish.

Color.-Type: Upperparts orange ochraceous, darkening toward ochraceous rufous on outer surface of legs, and lightening to a buff considerably yellower than that of Ridgway on sides, the hairs everywhere pale ecrudrab at extreme base and black at tip. The black tips produce a heavy shading on both back and sides. On the former it is slightly in excess of the orange ochraceous, but on sides the two colors, as seen in the skin, are about equally mixed. Throughout, the grizzle caused by the contrasting colors is more coarse and conspicuous than in Tragulus pretiosus, a difference which may prove to be seasonal. Neck mostly black, this color clear and unmarked immediately behind occiput, but elsewhere speckled with dull tawny ochraceous. At sides this speckling is rather conspicuous, but on dorsal surface it is not very noticeable except posteriorly. Crown black, slightly speckled with dull tawny ochraceous anteriorly. Cheeks and the usual superciliary stripe dull tawny ochraceous, slightly grizzled with black. Throat markings normal, the dark bands black, slightly speckled with tawny ochraceous;

$a$ Proc. Acad. Nat. Sci. Philadelphia, 1902, p. 127, June 4, 1902.

${ }^{b}$ For the opportunity to examine the Lampong material I am indebted to the kindriess of Mr. Witmer Stone and the authorities of the Philadelphia Academy of Natural Sciences.

c Miller, Proc. Acad. Nat. Sci. Philadelphia, 1902, p. 145, June 11, 1902. 
the light stripes pure white. Collar broad and distinct, concolor with sides of body. Underparts and stripe down inner surface of legs white, a narrow brownish longitudinal line along middle of chest, and a faint buffy suffusion on middle of belly. Tail lacking in the type. In an immature female it is similar to back above, but duller and less washed with black, pure white below and at tip.

Skull and teeth.-The skull and teeth are rather smaller than in Tragulus napu and $T$. nigricollis, about equaling those of $T$. pretiosus. In form they show no peculiarities worthy of note, though the skull is relatively broader than in the Sumatran animal.

Measurements. ${ }^{a}$-External measurements of type: Head and body, 520 ; hind foot, 129 (115); ear from meatus, 32; ear from crown, 27; weight, 2.7 kilograms.

Cranial measurements of type: Greatest length, $108.6(116) ;^{b}$ basal length, 101.4 (108); basilar length, 96 (99); occipito-nasal length, 98 (104); length of nasals, 33 (32); greatest breadth of both nasals together, 13 (13.4); diastema, 11 (10.6); zygomatic breadth, 47 (47); least interorbital breadth, 31.4 (31.4); mandible, 86 (88); maxillary tooth row (alveoli), 35 (37); maxillary premolars (crowns), 18.4 (18.4); mandibular tooth row (alveoli), 42 (42); mandibular premolars (crowns), 19 (19).

Specimens examined.-Two, both from Pulo Mansalar.

Remarks.-While Tragulus amonus is very different from the grayish T. napu of the near-by mainland, it rather closely resembles the yellowish $T$. pretiosus and $T$. nigricollis from Linga and Sinkep islands off the east coast of Sumatra. The details of its characters, however, readily distinguish it from both of these.

TRAGULUS JUGULARIS, new species.

Type.-Adult male (skin and skull), Cat. No. 114574, U.S.N.M. Collected on Pulo Mansalar, off Tapanuli Bay, Sumatra, March 8, 1902, by Dr. W. L. Abbott. Original number, 1627.

Characters.-Size about as in Tragulus amconus. No white anywhere. Apparently rather closely resembling Tragulus anno Matschie, ${ }^{c}$ but ear smaller, and dark loral stripe and light bands on throat clearly indicated.

Color.-Type: With the exception of the under parts, inner surface of legs, and under surface of tail, the color is almost exactly as in the type of Tragulus amanus. The neck, however, is less speckled with tawny ochraceous, and the cheeks and superciliary stripes are somewhat more washed with black. This wash is not enough to obscure

$a$ The measurements in this paper are all in millimeters.

${ }^{b}$ Measurements in parentheses are those of an adult male Tragulus napu from Tapanuli Bay, Sumatra (No. 114434).

$c$ Sitz-Ber. Gesellsch. naturforsch. Freunde zu Berlin, 1897, p. 157. 
the strong contrast between the superciliary stripes and the black, very obscurely grizzled crown. Inner surface of legs, under surface of tail, and entire ventral surface behind throat markings orange buff, brighter on legs and middle of chest, duller on tail, and paler and more gray in axillary and hypogastric regions; middle of belly with a distinct dusky wash. The portion of chin normally white is concolor with cheeks, and the light throat stripes are merely indicated by a stronger grizzle of tawny ochraceous in the general black of the throat. This indication, however, is so distinct that it can not be overlooked, and in many specimens it is even more evident than in the type. In none of the 17 examined is it absent. The pattern thus outlined is in every respect normal. Collar of normal extent, but rather more tawny than in Tragulus amcenus. Ears, naked area around and in front of eyes, feet, and lower half of tarsus and carpus covered with minute blackish hairs.

The series is very uniform in color. Some variation is shown in the distinctness with which the throat markings are indicated, and in the amount of dusky wash on the belly. In many skins the blackish hairs on feet and distal portion of legs are mostly replaced by tawny, but in general the dusky feet are characteristic. None shows distinct white on any part of the body.

Skull and teeth.- While the skull is smaller than that of Tragulus napu, I can see nothing to distinguish it from that of $T$. amonus, with which it agrees in both size and form. The teeth, on the other hand, particularly the premolars, are distinctly larger than in the related species.

Measurements.-External measurements of type: Total length, 578; head and body, 513; tail vertebræ, 65; hind foot, 130 (114); ear from meatus, 28; ear from crown, 25; weight, 2.4 kilograms. Average of five adult males from the type locality: Total length, 587 (575-618); head and body, $514(505-538)$; tail vertebræ, 72.6 (65-80); hind foot, 130.2 (126-133); hind foot without hoofs, 115.4 (111-119). Average of ten adult females from the type locality: Total length, $610(570-$ $670)$; head and body, 536 (495-590); tail vertebræ, $74.2(65-80)$; hind foot, 132.9 (128-138); hind foot without hoofs, 118.5 (111-124). For details see table, p. 442 .

Cranial measurements of type: Greatest length, 106; basal length, 99; basilar length, 92; occipito-nasal length, 97; length of nasals, 28.6; greatest breadth of both nasals together, 13 ; diastema, 8.8; zygomatic breadth, 45; least interorbital breadth, 29; mandible, 85; maxillary tooth row (alveoli), 38.6; maxillary premolars (crowns), 20; mandibular tooth row (alveoli), 45; mandibular premolars (crowns), 20.6.

Specimens examined.-Seventeen, all from Pulo Mansalar.

Remarks. - The only species with which this animal needs comparison is the Tragulus annæ, described by Matschie from specimens from an 
unknown locality. The main points of difference are as follows: In Tragulus annæe there is no trace of the pale throat markings ${ }^{a}$ or of the black loral stripe ${ }^{b}$ all of which are present in T. jugularis; the length of ear is stated to be $37 \mathrm{~mm}$., while in none of the specimens of $T$. jugularis does this measurement, taken with the greatest possible amplitude, exceed $32 \mathrm{~mm}$.

Measurements of Tragulus of the Napu group.

\begin{tabular}{|c|c|c|c|c|c|c|c|c|}
\hline Name. & Locality. & Number. & Sex. & $\begin{array}{c}\text { Total } \\
\text { length. }\end{array}$ & $\begin{array}{l}\text { Head } \\
\text { and } \\
\text { body. }\end{array}$ & $\begin{array}{c}\text { Tail } \\
\text { verte- } \\
\text { bræ. }\end{array}$ & $\begin{array}{l}\text { Hind } \\
\text { foot. }\end{array}$ & $\begin{array}{l}\text { Hind } \\
\text { foot } \\
\text { with- } \\
\text { out } \\
\text { hoofs. }\end{array}$ \\
\hline Tragulus napu.... & Tapanuli Bay ... & 114432 & Male young ... & $m_{560}$ & $\begin{array}{r}m m . \\
480\end{array}$ & $\mathrm{~mm}_{80}$ & $\begin{aligned} m m . \\
135\end{aligned}$ & $\mathrm{~mm}_{120}$ \\
\hline 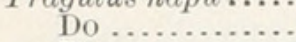 & ..... do .......... & 114433 & $\ldots$. do ......... & 425 & 370 & 55 & 120 & 107 \\
\hline Do ... & .... do $\ldots$......... & 114434 & Male adult ... & 620 & 550 & 70 & 147 & 130 \\
\hline Do $\ldots \ldots \ldots \ldots$ & .....do........... & 114435 & Male young ... & 530 & 470 & 60 & 135 & 121 \\
\hline Tragulus amœnus... & Pulo Mansalar.. & $141 \supset 62$ & Female young & 498 & 433 & 65 & 119 & 117 \\
\hline Do $\ldots \ldots \ldots \ldots$ & ..... do ........... & a 114563 & Male adult .... & & 520 & & 129 & 115 \\
\hline Tragulus jugularis.. & ...do. & 114564 & Female adult. & 590 & 515 & 75 & 128 & 111 \\
\hline Do $\ldots \ldots \ldots$ & .... do .... & 114565 & Female young & 560 & 480 & 80 & 131 & 115 \\
\hline Do & .. do. & 114566 & Female adult. & 59 & 515 & 80 & 13 & 120 \\
\hline Do & ...do. & 114567 & ..... do ......... & 597 & 532 & 65 & 130 & 117 \\
\hline Do & .. do & 114568 & ..do. & 57 & 495 & 75 & 13 & 118 \\
\hline Do & .....do & 114569 & do & 580 & 500 & 80 & 138 & 123 \\
\hline Do & $\therefore$ do & 114573 &.$d$ & 67 & 590 & 80 & 13 & 120 \\
\hline Do & ... do & 114576 & .. do . & b 558 & 540 & $b 18$ & 133 & 118 \\
\hline Do & .. do & 114577. & ..d & 650 & 580 & 70 & 13 & 115 \\
\hline Do & ... do. & 114579 & $\ldots . d \mathrm{~d}$ & 62 & 558 & 70 & 137 & 124 \\
\hline Do & .. do & 114580 & ..... de & 60 & 533 & 73 & 133 & 119 \\
\hline Do & ... do ... & 114570 & Male adult ... & 58 & 510 & 75 & 13 & 119 \\
\hline Do & ... do & 114571 & ..... do ......... & 57 & 505 & 73 & 12 & 115 \\
\hline Do & $\ldots$ do ... & 114572 & Male & 51 & 45 & 65 & 118 & 104 \\
\hline Do & d & a 114574 & Male adult ... & 578 & 513 & 65 & 130 & 114 \\
\hline Do & ..... do .... & 114575 & ..... do .......... & 618 & ธั3 & 80 & 13 & 118 \\
\hline Do. & & 114578 & .....do.. & & 505 & 70 & 126 & 111 \\
\hline
\end{tabular}

a Type.

$b$ Tail imperfect.

\section{TRAGULUS KANCHIL (Raffles).}

1822. Maschus kanchil Raffles, Trans. Linn. Soc. London, XIII, p. 262; Bencoolen, Sumatra,

1902. Tragulus kanchil Stone and Renn, Proc. Acad. Nat. Sci. Philadelphia, 1902, p. 128, June 4, 1902.

Twelve specimens were taken at Tapanuli Bay, Sumatra. For measurements, see table, page 446 . In nine of these the diagonal dark throat stripes are united anteriorly, while in three they are separated by the forward prolongation of the median white stripe. The series is very uniform in both size and coloration, and none of the specimens show any approach toward the peculiarities of the forms inhabiting the Banjak Islands.

$a$ Die Halsgegend ist ringsherum tief schwarzbraun und zeigt keine Spur von hellen Binden an der Vorderseite und an der Oberbrust.

$b$ Vom Auge zur Nase ist ein dunkler Streif nicht wahrnehmbar, sondern der Kopf ist ebenso gefärbt wie der Rücken und nur über den Augen und auf der Oberlippe ist ein heller Strich angedeutet. 
TRAGULUS BREVIPES, new species.

Type.-Adult female (skin and skull). Cat. No. 114326, U.S.N.M. Collected on Pulo Bangkaru, Banjak Islands, January 20, 1902, by Dr. W. L. Abbott. Original number, 1443.

Characters. -General size as in Tragulus kanchil, but ears and feet much shorter. Coloration slightly paler than in the Sumatran animal, but of exactly the same type. Skull with rostral portion more slender than in the related species.

Color.-Back a fine grizżle of black and light orange-buff, the former slightly in excess. Sides buff-yellow, a little clouded by the black hair-tips. Outer surface of legs bright orange-buff, the hairs of the front legs with faintly indicated black tips, those of the hind legs rather strongly shaded with black. Nape-stripe clear black, sharply contrasted with the dull, slightly grizzled, orange-buff sides of neck. Crown blackish, the hairs very obscurely annulated with dull yellowish brown. Cheek from below outer canthus of eye to muzzle dirty cream color, in rather strong contrast with surrounding parts. Under parts and inner surface of legs white. Median line of chest with a narrow, grizzled brown stripe, and middle of belly with an obscure buffy wash. Throat pattern normal, the brown stripes strongly grizzled and considerably darker than sides of neck, confluent in front. Collar narrow but well defined, concolor with sides of neck. Tail clear, dull, orange-buff above, pure white below and at tip.

Skull and teeth.- In size and general form the skull closely resembles that of Tragulus kanchil and T. russeus, but the rostrum is distinctly narrower than in any of the specimens of the related speciesa difference easily appreciable on comparison. Teeth as in Tragulus kanchil.

Measurements.-External measurements of type: Total length, 520; head and body, 450; tail vertebræ, 70; hind foot, 108 (98).

Cranial measurements of type: Greatest length, $97(95) ;^{a}$ basal length, 90 (89); basilar length, 85 (83); diastema, 11.4 (10.4); length of nasals, 29.6 (28); greatest breadth of nasals posteriorly, 12 (12.6); least interorbital breadth, $26(28)$; breadth of palate at middle of diastema, 11 (13.6); zygomatic breadth, 42 (42); mandible, 77 (73); maxillary tooth row (alveoli), 34 (32.6); mandibular tooth row (alveoli), $41.4(35)$.

Specimens examined.-One, the type.

Remarks.-In its small feet and pale color Tragulus brevipes suggests T. pallidus, but the latter is a much more pallid animal and its skull has an exceedingly short, heavy rostrum.

${ }^{a}$ Measurements in parenthesis are those of an adult female Tragulus kanchil from Tapanuli Bay, Sumatra (No. 114421). 
TRAGULUS RUSSEUS, new species.

Type.-Adult male (skin and skull), Cat. No. 114337, U.S.N.M. Collected on Pulo Tuangku, Banjak Islands, February 15, 1902, by Dr. W. L. Abbott. Original number, 1518.

Characters. - Size and general appearance as in Tragulus fulviventer Gray, ${ }^{a}$ but brown throat stripes not as dark and white stripes often obsolete and occasionally absent.

Color.-Type: General color above orange-ochraceous, slightly paler on sides and darkening to raw sienna on neck and outer surface of limbs. The hairs of the back are tipped with black, which, when the fur is undisturbed, forms a dark shading decidedly in excess of the orange-ochraceous. Across shoulders this shading deepens rapidly into the clear black nape stripe. On sides of body and neck the lighter color is in excess of the black, which practically disappears along lower edge of sides, where the color passes into the clear raw sienna of legs and very pale orange-ochraceous with which the under parts are suffused. Crown blackish, strongly grizzled with yellowish brown. Cheeks distinctly paler than neck, the exact color intermediate between the buff-yellow and straw-yellow of Ridgway. Muzzle darker and duller than cheeks. An indistinet pale line borders dark color of crown from ear to muzzle. Ears blackish. Chest and belly pale orange-ochraceous, fading nearly to ochraceous buff in axillary region, and with white markings as follows: (1) A large patch in hypogastric region, continued downward along inner side of hind legs and forward as two narrow stripes to about level of diaphragm; and (2) a narrow stripe on each side of median line of chest. Chin white to about 10 mm. behind median bare area, the posterior outline of the white nearly straight, and $55 \mathrm{~mm}$. in length. Behind this the region usually occupied by the white throat stripes presents a peculiar mottled aspect, due to the fact that the white is mostly replaced by clear orange-ochraceous, which forms no distinct contrast with the collar and dark stripes, both of which are essentially like sides of neck, therefore distinctly grizzled. The white persists as a semilunar spot $20 \mathrm{~mm}$. wide by $10 \mathrm{~mm}$. long (the concavity directed backward), the remnant of the posterior extremity of the median stripe, and a very faint, easily overlooked trace of each of the lateral stripes. The collar sends back a dark median stripe 90 $\mathrm{mm}$. in length between the two white chest stripes. Inner surface of front leg with a few whitish hairs, not enough to produce a white area. Tail white beneath and at tip, concolor with flanks above.

While the type represents the more extreme phase of the species, one specimen (female Cat. No. 114336, U.S. N. M., original number 1507), carries the peculiarities much further. In this the white is all replaced 
by orange-ochraceous except a very narrow line along under surface of tail, and two faint traces $20 \mathrm{~mm}$. in length on middle of chest. In the majority of specimens the under parts are as in the type, except that the white areas are slightly more extended and the throat markings are normal in extent and pattern. The dark throat stripes, however, are never as dark as those of $T$. kanchil or as those of the specimen described as T. fulviventer by Stone and Rehn.

Skull and teeth.-Except that they are larger throughout, the skull and teeth are essentially as in the Tragulus fulviventer of Stone and Rehn.

Measurements. - External measurements of type: Total length, 505 $(440){ }^{a}$ head and body, $455(400)$; tail vertebræ, 60 (40); hind foot, 120 (113); hind foot without hoofs, 110 (103); ear from meatus, 29 (-); ear from crown, 22 (15). Average of eight males from the type locality: Total length, 531 (505-563); head and body, 467 (450-493); tail vertebræ, 65 (55-70); hind foot, 120.3 (116-125); hind foot without hoofs, 107.9 (104-113). Average of four females from the type locality: Total length, $525(500-540)$; head and body, 458 (435-470); tail vertebræ, $68.8(65-70)$; hind foot, $118.8(117-120)$; hind foot without hoofs, 107.3 (106-109). For details see table, page 446.

Cranial measurements of type: Greatest length, $99(-) ;^{a}$ length from inion to tip of premaxillaries, 97 (86); basal length, $91(-)$; basilar length, $85(-)$; length of nasals, $31.4(24)$; diastema, 8 (7); zygomatic breadth, $45(41)$; least interorbital breadth, 28 (25); width of palate between anterior molars, $17.8(16.4)$; front of orbit to tip of premaxillary, 44.4 (41.6); mandible, 78 (73); maxillary toothrow (alveoli), 35 (32); mandibular toothrow (alveoli), 41 (37).

Specimens examined.-Fifteen, all from Pulo Tuangku.

Remarks.-This species is readily distinguishable from Tragulus kanchil by its smaller size, brighter, more fulvous color, the greater extension of the fulvous wash on belly and chest, and the character of the throat markings. It is evidently more closely related to Tragulus fulviventer. With this animal it agrees in size and in the general type of coloration, but differs in the very light color of the brown throat markings and the tendency of the white stripes to become obsolete, in the latter peculiarity showing an interesting parallelism with Tragulus jugularis of Pulo Mansalar. Of Tragulus fulviventer I have examined the specimen described by Stone and Rehn, and Mr. Oldfield Thomas has sent the following measurements of Gray's type, an adult female in the British Museum: Head and body (skin), 450; hind foot with hoof, 122; basal length of skull, 84; palatal length, 59; interorbital breadth, 24.5; combined length of three upper premolars, 18.5 ; combined length of three lower premolars, 18.5.

a Measurements in parentheses are those of the specimen Tragulus fulviventer of Stone and Rehn, male adult, No. 642, Philadelphia Academy of Sciences. 
Measurements of Tragulus of the kanchil group.

\begin{tabular}{|c|c|c|c|c|c|c|c|c|}
\hline Name. & Locality. & Number. & Sex. & $\begin{array}{c}\text { Total } \\
\text { length. }\end{array}$ & $\begin{array}{l}\text { Head } \\
\text { and } \\
\text { body. }\end{array}$ & $\begin{array}{c}\text { Tail } \\
\text { verte- } \\
\text { bræ. }\end{array}$ & $\begin{array}{l}\text { Hind } \\
\text { foot. }\end{array}$ & $\begin{array}{l}\text { Hind } \\
\text { foot } \\
\text { with- } \\
\text { out } \\
\text { hoofs. }\end{array}$ \\
\hline & Tapanuli Bay... & 114417 & Male adult ... & ${ }_{503}^{m}$. & $\begin{array}{c}m m . \\
433\end{array}$ & $m_{70}$ & $\begin{array}{c}m m . \\
123\end{array}$ & $\mathrm{~mm}_{\text {i11 }}$ \\
\hline $\begin{array}{r}\text { Tragulus kanchit ... } \\
\text { Do ................. }\end{array}$ & ..... do............ & 114418 & ..... do ........ & 520 & 440 & 80 & 127 & 115 \\
\hline Do .................. & $\ldots$. do $\ldots . . . . .$. & 114419 & $\ldots$... do .... & 507 & 432 & 75 & 118 & 107 \\
\hline Do & ....do. & 114420 & ..... do ... & 537 & 442 & 95 & 128 & 115 \\
\hline Do & .. do. & 114426 & ..... do.. & 485 & 425 & 60 & 121 & 108 \\
\hline Do & .... do . & 114427 & $\ldots \ldots$ do....... & 500 & 430 & 70 & 124 & 111 \\
\hline Do & ... do & 114421 & Female adult. & 548 & 468 & 80 & 128 & 115 \\
\hline Do & ... do & 114422 & ..... do ......... & 537 & 457 & 80 & 12 & 114 \\
\hline Do & ... do & 114423 & ..... do ........ & 545 & 470 & 75 & 120 & 108 \\
\hline Do . & ... do & 114424 & ..... do & 535 & 465 & 70 & $1:$ & 109 \\
\hline Do . & ... do & 114425 & ..... do & 520 & 450 & 70 & 125 & 113 \\
\hline Do $\ldots \ldots \ldots$. & $\ldots$ do $\ldots$....... & 114428 & ..... do . & 495 & 430 & 65 & 121 & 108 \\
\hline Tragulus brevipes... & Pulo Bangkaru. & 114326 & $\ldots \ldots$ do $\ldots \ldots$. & 520 & 450 & 70 & 109 & 98 \\
\hline Tragulus russeus ... & Pulo Tuangku.. & 114328 & Male adult . & b 510 & 480 & $b 30$ & 118 & 104 \\
\hline Do $\ldots \ldots \ldots$. & ..... do ... & 114329 & ..... do ...... & 563 & 493 & 70 & 122 & 110 \\
\hline Do . & ..... do. & 114331 & . do & 520 & 455 & 65 & 123 & 110 \\
\hline Do & do & 114333 & ..... do . & 540 & 470 & 70 & 120 & 107 \\
\hline Do & do. & a 114337 & .. do & 515 & 455 & 60 & 116 & 104 \\
\hline Do & do & 114339 & . do & c 520 & $c 445$ & $c 65$ & 118 & 107 \\
\hline Do & do & 114340 & $\ldots$. do $\ldots$... & 555 & 485 & 70 & 125 & 113 \\
\hline Do &.$d o$ & 114341 & Male youn & 500 & 430 & 70 & 110 & 98 \\
\hline Do & . do & 114342 & Male adult ... & 505 & 450 & 55 & 120 & 108 \\
\hline Do & do & 114330 & Female adult. & 540 & 470 & 70 & 119 & 107 \\
\hline Do & $d 0$ & 114332 & $\ldots .$. do $\ldots . . . .$. & 520 & 455 & 65 & 120 & 109 \\
\hline Do & .. & 114334 & Female young & 382 & 327 & 55 & 100 & 89 \\
\hline Do & & 114335 & ..... do ......... & 500 & 435 & 65 & 110 & 98 \\
\hline Do & ... do & 114336 & Female adult. & 500 & 435 & 70 & 117 & 106 \\
\hline Do $\ldots \ldots \ldots \ldots$ & ..... do .......... & 114338 & $\ldots \ldots$ do $\ldots \ldots \ldots$ & 540 & 470 & 70 & 119 & 107 \\
\hline
\end{tabular}

\section{FAMULY SUID A.}

\section{SUS VITTATUS Müller and Schlegel.}

1839-1844. Sus vittatus Müller and Schlegel, Verhandel. over de natuurlijke Geschiedenis der Nederl. overzeesche bezittingen, p. 173; Java.

Nine specimens (skins with skulls) as follows: Simalur Island, 4; Pulo Babi, 3; Pulo Tuangku, 2. For measurements see table, p. 446.

It is possible that more than one form is represented by this series. The pig of Simalur Island is considerably smaller than that of Pulo Babi; and that of Pulo Tuangku, judged by the skulls rather than by the external measurements, is intermediate in size, though near the Pulo Babi animal. In the absence of Javan material, however, it seems unsafe to attempt to distinguish the insular races.

Measurements of Sus vittatus.

\begin{tabular}{|c|c|c|c|c|c|c|c|}
\hline Locality. & Number. & Sex. & $\begin{array}{c}\text { Total } \\
\text { length. }\end{array}$ & $\begin{array}{l}\text { Head } \\
\text { and } \\
\text { body. }\end{array}$ & Tail. & $\begin{array}{l}\text { Hind } \\
\text { foot. }\end{array}$ & $\begin{array}{l}\text { Hind } \\
\text { foot } \\
\text { with- } \\
\text { out } \\
\text { hoof. }\end{array}$ \\
\hline 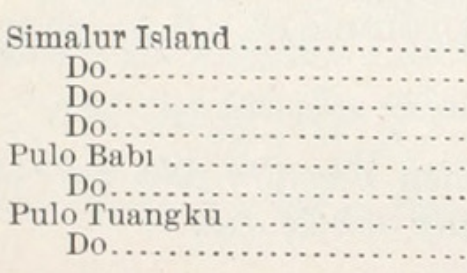 & $\begin{array}{l}114177 \\
114179 \\
114180 \\
114178 \\
114282 \\
114283 \\
114415 \\
114416\end{array}$ & 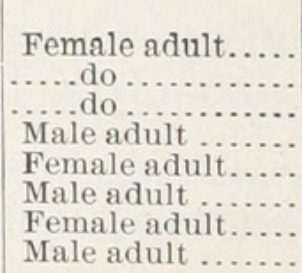 & $\begin{array}{l}m m \\
1,185 \\
1,245 \\
1,125 \\
1,375 \\
1,320 \\
1,420 \\
1,380 \\
1,300\end{array}$ & $\begin{array}{l}m m . \\
1,030 \\
1,070 \\
995 \\
1,175 \\
1,120 \\
1,200 \\
1,170 \\
1,060\end{array}$ & $\begin{array}{l}m m \\
155 \\
175 \\
130 \\
200 \\
200 \\
220 \\
210 \\
240\end{array}$ & $\begin{array}{r}m m . \\
222 \\
213 \\
212 \\
244 \\
245 \\
250 \\
230 \\
265\end{array}$ & $\begin{array}{r}m m . \\
182 \\
178 \\
179 \\
206 \\
195 \\
210 \\
190 \\
225\end{array}$ \\
\hline
\end{tabular}




\section{FAMILY SCIURIDA.}

RATUFA FEMORALIS, new species.

Type-Adult female (skin and skull), Cat. No. 114361, U.S.N.M. Collected on Pulo Tuangku, Banjak Islands, January 27, 1902, by Dr. W. L. Abbott. Original number, 1479.

Characters. - General appearance as in Ratufa bunguranensis, but color, particularly of face, feet, and under parts not as dark, and short hair of under surface of tail not forming a conspicuous, dark, median stripe. Pale flank patch more conspicuous than in any other known species.

Color.-Type: Upper parts and outer surface of limbs raw sienna, everywhere overlaid with pale ecru-drab, the combination very difficult to describe. The shorter hairs are raw sienna throughout (except slate-gray base), the longer, coarser ones light ecru-drab with indistinct dark tips. Many of the longer hairs are rather distinctly annulated. The general effect is intermediate between the clear, pale, upper surface of Ratufa affinis and the distinctly grizzled $R$. pyrsonota. On crown and forehead the brown nearly disappears and the ecru-drab lightens almost to cream color. On sides of body and outer surface of legs the ecru-drab gradually gives place to the raw sienna, which darkens nearly to tawny on forearm. Under parts and inner surface of legs raw sienna, paler and duller than that of back and sides and fading almost to buff in axillary region and at front of thigh. Pale flank patch well defined, whitish cream buff in strong contrast with surrounding parts. Cheeks and chin to level of ears grizzled smoke gray. Patch $10 \mathrm{~mm}$. in diameter at base of whiskers, whitish gray. Ears concolor with cheeks internally, prouts brown externally. Feet prouts brown, blackening on toes, the brown extending around wrists and ankles, but much mixed with raw sienna on inner side. Tail dark prouts brown, irregularly washed with raw umber (somewhat paler than that of Ridgway), perhaps as the result of incipient bleaching. Most of the hairs of the sides of the tail are dull buff from base to about middle. This color produces a faintly suggested light median area on under surface, but not distinctly enough to form any marked contrast with edge or with the short prouts-brown appressed hairs of median line.

Skull and teeth.-The skull and teeth closely resemble those of Ratufa bunguranensis, but the interpterygoid space and nasal branches of the premaxillaries are narrower, and the premolar, both above and below, is larger.

Measurements.-External measurements of type: Total length, 690; head and body, 320; tail vertebræ, 370; hind foot, 72 (68). Average of eight adults from type locality: Total length, $700(670-740)$; head and body, 321 (310-335); tail, 378 (360-405); hind foot, 72.6 (70-76); hind foot without claws, 67 (65-69). For details see table, page 450 . 
Cranial measurements of type: Greatest length, 62; basal length, 52 ; basilar length, 49; length of nasals, 20; least interorbital breadth, 23.4; zygomatic breadth, 37; mandible, 36.6; maxillary molar series (alveoli), 12.8; mandibular molar series (alveoli), 13.6.

Specimens examined. -Eight, all from Pulo Tuangku.

Remarks. - This squirrel is undoubtedly a near ally of the Ratufa affinis aureiventer of Bonhote. ${ }^{a}$. It differs so widely, however, from Geoffroy's original description of Sciurus aureiventer that I have no hesitation in applying to it a new name.

\section{RATUFA NIGRESCENS, new species.}

Type-Adult female (skin and skull), Cat. No. 114556, U.S.N.M. Collected on Pulo Mansalar off Tapanuli Bay, Sumatra, March 11, 1902, by Dr. W. L. Abbott. Original number 1641.

Characters.-One of the largest known members of the affinisbunguranensis group. Color pattern as in Ratufa bunguranensis and $R$. femoralis, but upper parts and tail darkened almost to black. Pale flank patch obsolete.

Color.-Type: The upper parts at first sight appear to be black, but on closer inspection the color is seen to be seal brown, which in certain lights shows faint traces of raw umber. On sides of body and neck and outer surface of legs the raw umber slightly predominates and the hairs show a fine grizzle, due to minute annulations of the lighter color. Under parts and inner surface of legs raw umber, paler in axillary region and at front of thigh. Pale flank patch barely indicated by a sprinkling of cream buff hairs. Cheeks and chin to level of ears a fine grizzle of blackish and whitish; region surrounding base of whiskers slightly paler. Ears blackish externally, concoler with cheeks internally. Feet blackish. Tail uniform seal brown like back above, the basal half of the hairs tinged with dull raw umber. This color appears irregularly at the surface when hairs are disarranged, but without forming any noticeable contrast with the seal brown. The under surface of tail appears at first sight the same as the upper, but on disarranging the hairs many of them are seen to be rather thickly annulated with cream buff bands, of which there are usually about six, for the most part confined to the basal half. In certain lights these annulations produce the faint indication of a light median area, most noticeable on basal third of tail.

Skull and teeth. - The skull and teeth show no marked peculiarities. In general form the skull is longer and narrower than that of Ratufa bunguranensis. Teeth, as in $R$. bunguranensis, therefore relatively smaller than in $R$. femoralis.

Measurements.-External measurements of type: Total length, 750 head and body, 340; tail vertebræ, 410; hind foot, 78 (70). A Average of five adult females from the type locality: Total length, $728(705-750)$ 
head and body, $332(320-340)$; tail vertebræ, 396 (365-410); hind foot, 77.2 (75-79); hind foot without claws, 70.4 (69-72). For details see table, page 450 .

Cranial measurements of type: Greatest length, $66(64) ;^{a}$ basal length, 55 (54); basilar length, $52(50)$; length of nasals, 21.4 (21); least interorbital breadth, 25 (26); zygomatic breadth, 38 (40); mandible, 40.4 (40); maxillary tooth row, 13 (12.6); mandibular tooth row, 14 (13).

Specimens examined.-Five, all from the type locality.

Remarks.--The five specimens of Ratufa nigrescens show no individual variation worthy of note. This squirrel - one of the most striking of the genus - is immediately recognizable by its rich blackish-brown upper parts and tail and yellowish-brown under parts. The tail is apparently more bushy than in the related species.

\section{RATUFA PALLiATA Miller.}

1902. Ratufa bicolor hypoleuca Stone and Rehn, Proc. Acad. Nat. Sci. Philadelphia, 1902, p. 134, June 4, 1902. Not Sciurus hypoleucos Horsfield.

1902. Ratufa palliata Miller, Proc. Acad. Nat. Sci. Philadelphia, 1902, p. 147, June 11, 1902; Indragiri River, Sumatra.

An immature female was taken at Tapanuli Bay, Sumatra, March 28,1902 . For measurements see table, page 450 . It closely agrees with the original specimens of Ratufa palliata and with the skin from the Lampong district, recorded by Stone and Rehn as $R$. hypoleuca. ${ }^{b}$

RATUFA LÆNATA, new species.

(Plate XIX.)

Type.-Adult male (skin and skull), Cat. No. 114350, U.S.N.M. Collected on Pulo Tuangku, Banjak Islands, January 27, 1902, by Dr. W. L. Abbott. Original number, 1478.

Characters.-Externally similar to Ratufa palliata, but hind foot not as long (see table of measurements, p. 450); general form of skull as in $R$. palliata, but nasal branches of premaxillaries extending farther behind nasals, and anterior median termination of maxillaries narrower.

Color.-The color of Ratufa lænata so closely resembles that of $R$. palliata as to need no detailed description. The twelve skins show considerable variation in color, due partly to the greater or less suffusion of dark brown in the mantle, and partly to bleaching. None, however, shows any approach toward $R$. bicolor or $R$. melanopepla.

Skull and teeth.- While the general form of the skul! shows no characters by which it may be distinguished from that of Ratufa palliata, the outline of certain individual bones is peculiar to the Tuangku animal. In $R$. palliata the premaxillaries scarcely extend behind the nasals, while in $R$. lænata their posterior extremity is

${ }^{a}$ Measurements in parentheses are those of a considerably older female of Ratufa bunguranensis (No. 104636).

${ }^{b}$ For the opportunity to examine this specimen I am indebted to the kindness of Mr. Witmer Stone and the officers of the Academy of Natural Sciences of Philadelphia. 
usually from 2 to $4 \mathrm{~mm}$. behind that of nasals (see Plate XIX). The bony palate in $R$. lanata is narrower relatively to its length than in $R$. palliata, and the anterior extension of the maxillaries which runs forward between the posterior extremities of the premaxillaries to form hinder margin of incisive foramina is very noticeably narrower (see Plate XIX). In most of the skulls the anterior extremity of the interpterygoid space is narrower than in the related species, but their character is not wholly constant.

Teeth as in Ratufa palliata.

Measurements. - External measurements of type: Total length, 740; head and body, 330; tail vertebræ, 410; hind foot, 76 (68). Average of eleven adults from the type locality: Total length, 732 (710-765); head and body, 334 (325-345); tail vertebræ, 398 (380-420); hind foot, 75.8 (73-79); hind foot without claws, 68.7 (65-71). For details see table, page 450 .

Cranial measurements of type: Greatest length, 68.6 (68); ${ }^{a}$ basal length, 56.8 (57); basilar length, 52 (53); length of nasals, 22 (21); least interorbital breadth, 27 (29); zygomatic breadth, 41 (42); mandible, 43.4 (42); maxillary molar series (alveoli), 13 (12.8); mandibular molar series (alveoli), 13.6 (13.8).

Specimens examined. - Twelve, all from the type locality.

Remarks. - The characters which distinguish this squirrel from its nearest ally are of an unusual kind, but their constancy is such that they must be regarded as valid. Three skulls of adult Ratufa palliata have been compared with the twelve of $R$. lænata.

Measurements of Ratufa.

\begin{tabular}{|c|c|c|c|c|c|c|c|c|}
\hline Name. & Locality. & Number. & Sex. & $\begin{array}{c}\text { Total } \\
\text { length. }\end{array}$ & $\begin{array}{l}\text { Head } \\
\text { and } \\
\text { body. }\end{array}$ & Tail. & $\begin{array}{l}\text { Hind } \\
\text { foot. }\end{array}$ & $\begin{array}{l}\text { Hind } \\
\text { foot } \\
\text { with- } \\
\text { out } \\
\text { claws. }\end{array}$ \\
\hline 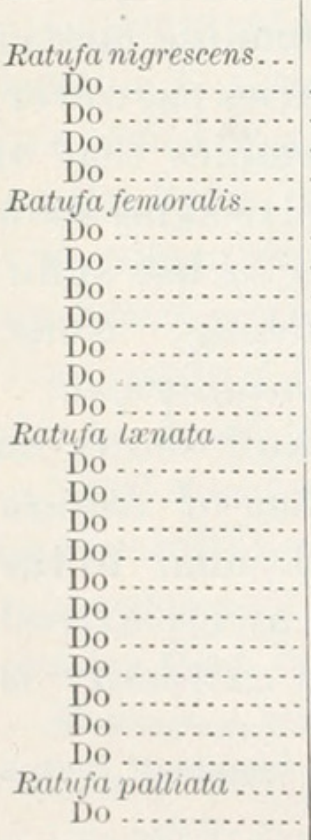 & 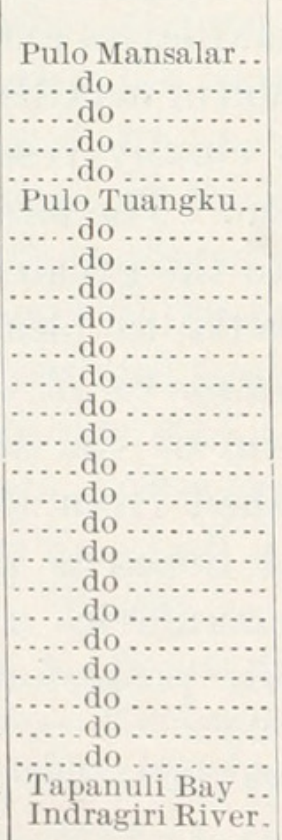 & $\begin{array}{r}114554 \\
114555 \\
114556 \\
114557 \\
114558 \\
114358 \\
114359 \\
114365 \\
114360 \\
a 114361 \\
114362 \\
114363 \\
114364 \\
114346 \\
114348 \\
a 114350 \\
114352 \\
114353 \\
114356 \\
114354 \\
114357 \\
114347 \\
114349 \\
114351 \\
114355 \\
114547 \\
a 113162\end{array}$ & 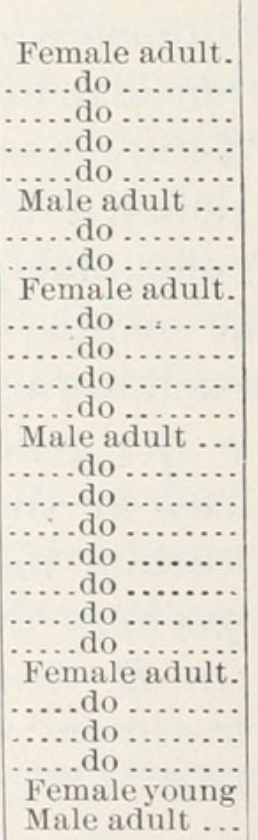 & $\begin{array}{r}m m . \\
730 \\
750 \\
750 \\
705 \\
705 \\
710 \\
710 \\
685 \\
715 \\
690 \\
680 \\
670 \\
740 \\
720 \\
720 \\
740 \\
755 \\
685 \\
735 \\
710 \\
725 \\
730 \\
730 \\
765 \\
720 \\
640 \\
770\end{array}$ & $\begin{array}{r}m m . \\
320 \\
340 \\
340 \\
320 \\
340 \\
325 \\
325 \\
310 \\
325 \\
320 \\
320 \\
310 \\
335 \\
335 \\
330 \\
330 \\
338 \\
315 \\
345 \\
340 \\
325 \\
330 \\
330 \\
345 \\
330 \\
270 \\
345\end{array}$ & $\begin{array}{r}m \text {. } \\
410 \\
410 \\
410 \\
385 \\
365 \\
385 \\
385 \\
375 \\
390 \\
370 \\
360 \\
360 \\
405 \\
385 \\
390 \\
410 \\
417 \\
370 \\
390 \\
380 \\
400 \\
400 \\
400 \\
420 \\
390 \\
370 \\
425\end{array}$ & \begin{tabular}{r|}
$m m$. \\
78 \\
79 \\
78 \\
75 \\
76 \\
71 \\
73 \\
72 \\
75 \\
72 \\
70 \\
72 \\
76 \\
76 \\
76 \\
76 \\
79 \\
72 \\
73 \\
77 \\
77 \\
76 \\
75 \\
76 \\
74 \\
80 \\
84
\end{tabular} & $\begin{array}{l}71 \\
72 \\
70 \\
69 \\
70 \\
66 \\
67 \\
67 \\
68 \\
68 \\
65 \\
66 \\
69 \\
68 \\
68 \\
68 \\
71 \\
65 \\
65 \\
70 \\
71 \\
68 \\
65 \\
7 \\
66 \\
7 \\
7 \\
6\end{array}$ \\
\hline
\end{tabular}


SCIURUS MANSALARIS, new species.

Type-Adult male (skin and skull), Cat. No. 114633, U.S.N.M. Collected on Pulo Mansalar, off Tapanuli Bay, Sumatra, March 2, 1902, by Dr. W. L. Abbott. Original number, 1583.

Characters. - Size and general appearance about as in Sciurus tenuis, but underparts clear gray as in S. brookei.

Color.-Upperparts, sides of body, and outer surface of limbs a uniform fine grizzle of raw sienna and black, neither of which distinctly predominates, though the raw sienna is slightly in excess on shoulders, flanks, and outer surface of legs. Feet and sides of head like back, but paler and more closely grizzled. Underparts and inner surface of legs mouse gray washed with dull white. On chest and hind legs there is a faint brownish tinge. Hairs of tail with six color bands: $(a)$ extreme base black, (b) $1.5 \mathrm{~mm}$. raw sienna, (c) $2 \mathrm{~mm}$. black, (d) $4 \mathrm{~mm}$. raw sienna, (e) $6 \mathrm{~mm}$. black, $(f) 4 \mathrm{~mm}$. whitish cream buff. The general effect above is a coarse grizzle, chiefly of black and whitish cream buff, through which the raw sienna appears when the hairs are disarranged. Below there is a broad median area of dull raw sienna edged with black, this fringed with whitish.

Skull and teeth.-The skull very closely resembles that of Sciurus tenuis but is a little narrower, longer, and deeper, characters that suggest, though very remotely, the much larger skull of $S$. brookei. Teeth as in Scuirus tenuis.

Measurements. - External measurements of type: Total length, 255; head and body, 140; tail vertebræ, 115; hind foot, 37 (35). Average of eight specimens from the type locality: Total length, 259 (245-278); head and body, 146.5 (135-158); tail vertebræ, 112 ( 8-122); hind foot, 37 (36-38); hind foot without claws, 35.4 (33-35). For details see table, page 452 .

Cranial measurements of type: Greatest length, 38; basal length, 32; basilar length, 29; length of nasals, 12; least interorbital breadth, 13; zygomatic breadth, 22.6 ; diastema, 8.8 ; mandible, 24 ; maxillary tooth row (alveoli), 7.4; mandibular tooth row (alveoli), 7 .

Specimens examined. - Eight, all from Pulo Mansalar.

Remarks.-This squirrel is readily distinguishable from Sciurus tenuis by its clear gray underparts, a character that gives it a close superficial resemblance to the much larger $S$. brookei of Borneo. Its relationships are undoubtedly with Sciurus tenuis, as the skull shows only a slight tendency toward the relatively narrow, elongate form characteristic of the Bornean species.

SCIURUS BANCARUS, new species.

Type--Adult male (skin and skull), Cat. No. 114311 U.S.N.M. Collected on Pulo Bangkaru, Banjak Islands, January 17, 1902, by Dr. W. L. Abbott. Original number, 1422. 
Characters. - Very similar to Sciumus mansalaris, but brown of upper parts more tinged with yellow and gray of underparts distinctly washed with whitish cream buff.

Measurements. - In size this animal closely agrees with Sciurus mansalaris, as shown by the table of measurements, page 452 .

specimens examined.-Ten, all from the type locality.

Remarks.--The characters which distinguish this squirrel from its relative of Pulo Mansalar are so scrictly comparative that it is impossible to state them in such a manner as to insure positive identification of single specimens. Comparison of the eight skins of one form with the ten of the other shows, however, that the slight differences are remarkably constant, so much so that, with the exception of a single specimen from each series, there is no difficulty in assigning every skin to its proper place.

\section{SCIURUS TENUIS Horsfield.}

1824. Sciurus tenuis Horsfield, Zoological researches in Java and the neighbouring islands (pages not numbered); Singapore.

Five skins from Tapanuli Bay, Sumatra. They are in all respects typical, and show no approach to Sciums mansalaris and S. bancarus. For measurements see table, page 452.

Measurements of Sciurus bancarus, S. mansalaris, and S. tenuis.

\begin{tabular}{|c|c|c|c|c|c|c|c|c|}
\hline Name. & Locality. & Number. & Sex. & $\begin{array}{c}\text { Total } \\
\text { length. }\end{array}$ & $\begin{array}{c}\text { Head } \\
\text { and } \\
\text { body. }\end{array}$ & Tail. & $\begin{array}{l}\text { Hind } \\
\text { foot. }\end{array}$ & $\begin{array}{l}\text { Hind } \\
\text { foot } \\
\text { with- } \\
\text { out } \\
\text { claws. }\end{array}$ \\
\hline 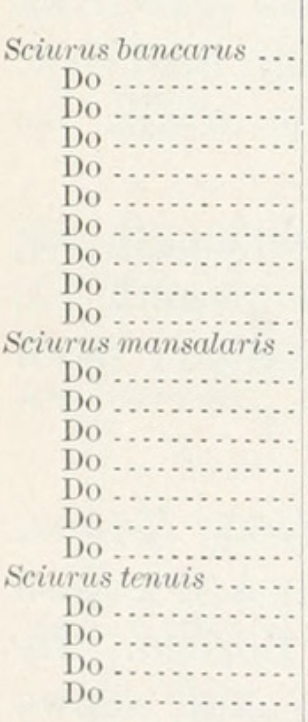 & 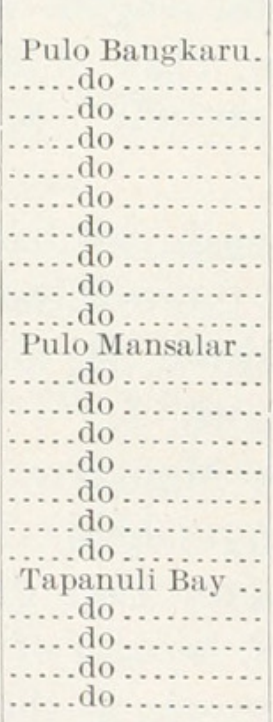 & $\begin{array}{r}114308 \\
114309 \\
a 114311 \\
114312 \\
114313 \\
114315 \\
114310 \\
114314 \\
114316 \\
114317 \\
114632 \\
a 114633 \\
114634 \\
114636 \\
114637 \\
114635 \\
114638 \\
114639 \\
114542 \\
114545 \\
114543 \\
114544 \\
114546\end{array}$ & 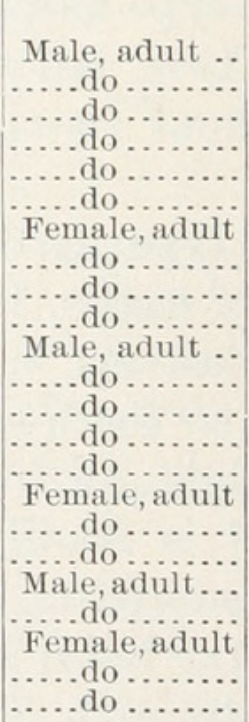 & $\begin{array}{c}m m . \\
262 \\
266 \\
260 \\
265 \\
267 \\
255 \\
264 \\
275 \\
253 \\
265 \\
245 \\
255 \\
270 \\
260 \\
255 \\
245 \\
278 \\
263 \\
255 \\
235 \\
255 \\
220 \\
235\end{array}$ & $\begin{array}{r}m m . \\
150 \\
160 \\
145 \\
145 \\
142 \\
162 \\
155 \\
150 \\
139 \\
145 \\
147 \\
140 \\
148 \\
150 \\
145 \\
135 \\
158 \\
150 \\
140 \\
120 \\
140 \\
117 \\
125\end{array}$ & $\begin{array}{r}m m . \\
112 \\
106 \\
115 \\
120 \\
125 \\
93 \\
109 \\
125 \\
114 \\
120 \\
98 \\
115 \\
122 \\
110 \\
110 \\
110 \\
120 \\
113 \\
115 \\
115 \\
115 \\
103 \\
110\end{array}$ & $\begin{array}{r}m m . \\
36 \\
36 \\
37 \\
35 \\
37 \\
35 \\
35 \\
37 \\
35 \\
36 \\
38 \\
37 \\
36 \\
36 \\
38 \\
36 \\
38 \\
37 \\
35 \\
34 \\
36 \\
34 \\
36\end{array}$ & $\begin{array}{c}m m . \\
32 \\
32 \\
34 \\
32.5 \\
34 \\
32 \\
32 \\
34 \\
32 \\
33 \\
35 \\
35 \\
33 \\
33 \\
35 \\
33 \\
35 \\
34 \\
32 \\
31.4 \\
33 \\
32 \\
33\end{array}$ \\
\hline
\end{tabular}

a Type.

\section{SCIURUS ALBESCENS (Bonhote).}

1901. Sciurus notatus albescens Bonнote, Ann. and Mag. Nat. Hist., 7th ser., VII, May, 1901, p. 446; Acheen, Sumatra.

Six specimens from Loh Sidoh Bay, practically topotypes of the species. For measurements see table, page 456 . 
This squirrel shows a striking and unexpected resemblance to the Sciurus abbottii of the Tambelan Islands. The skins are quite indistinguishable, except that the red element of the underparts is salmon rather than rusty. The skulls show certain slight though constant differences. The rostrum is somewhat broader proportionately to its length in the Sumatran animal, and the audital bullæ are more inflated. The maxillary teeth of Sciums albescens, while of the same general size as in $S$. abbottii, may be distinguished by their less thickened crowns, a character easily appreciated on comparison of the tooth rows viewed from the lingual side.

\section{SCIURUS VITTATUS Raffles.}

1822. Sciurus vittatus Raffles, Trans. Linn. Soc. London, XIII, p. 259; Bencoolen, Sumatra.

1901. Sciurus vittatus Bonнote, Ann. and Mag. Nat. Hist., 7th ser., VII, May, 1901, p. 447. (Part.)

Twelve specimens (two in alcohol, one skull without skin) from Tapanuli Bay, Sumatra. For measurements see table, page 456. The skins present no color variation worthy of note. In none is there any indication of such red in the tail as is characteristic of Sciurus miniatus, though a few show a tendency for the light annulations in the pencil to be more tinged with orange than they are elsewhere.

SCIURUS SATURATUS, new species.

Type--Adult female (skin and skull), Cat. No. 114629, U.S.N.M. Collected on Pulo Mansalar, off Tapanuli Bay, Sumatra, March 9, 1902, by Dr. W. L. Abbott. Original number, 1633.

Characters. - Similar to Sciurus vittatus but general color darker, pale lateral stripe less well defined, though of normal extent, and tail noticeably darker than back, its pencil mostly black.

Color.-Type: Upper parts and sides a uniform fine grizzle of black and ochraceous, the latter decidedly paler and less bright than that of Ridgway. The two colors are everywhere mixed in nearly equal quantity and the hair is distinctly glossy. Outer surface of legs somewhat paler and more buffy than back; cheeks and inner surface of ear decidedly so. A distinct buff eye ring. Muzzle marked with light grayish buff. Lateral stripes of normal extent, the upper one a light grayish buff, quite different from the grayish white stripe of $S$. vittatus. Tail essentially like back, but grizzle coarse, and black element more noticeable, particularly along edge and at tip, where the pencil is almost entirely black. Under parts and inner surface of legs intermediate between the ochraceous-rufous and tawny of Ridgway, but rather darker than either. This color extends to wrist and almost to heel.

Skull and teeth.-The skull and teeth resemble those of Sciurus vittatus, though perhaps averaging slightly larger. 
Measurements.-External measurements of type: Total length, 400; head and body, 215; tail vertebræ, 185; hind foot, 51 (47). Average of five adults from the type locality: Total length, 395 (375-411); head and body, 208 (185-221); tail vertebræ, 187 (180-190); hind foot, $51.4(51-52)$; hind foot without claws, 48 (47-49). For details see table, page 456 .

Cranial measurements of type: Greatest length, 52 (51); ${ }^{a}$ basal length, 43.6 (43); basilar length, 40 (40.2); length of nasals, $16.4(16)$; breadth of both nasals together anteriorly, 7.4 (8.2); diastema, 11.6 (11.8); least interorbital breadth, 18 (17.8); zygomatic breadth, 30 (30.4); mandible, 32.4 (31.4); maxillary tooth row (alveoli), 9.6 (9.6); mandibular tooth row (alveoli), 10 (9).

Specimens examined.-Five, all from Pulo Mansalar.

Remarks. - This is a well-marked form of the Sciurus notatus group, closely related to $S$. vittatus, but readily distinguishable by its dark general coloration, dull outer lateral stripe, and black-tipped tail. The series shows no variations worthy of special note.

SCIURUS PRETIOSUS, new species.

Type.-Adult female (skin and skull), Cat. No. 114325, U.S.N.M. Collected on Pulo Bangkaru, Banjak Islands, January 20, 1902. Original number, 1442.

Characters.-Like Sciurus saturatus, but average size less, red of underparts not as bright, tail not darker than back, and pencil not darker than rest of tail. Skull distinctly smaller than that of Sciurus saturatus.

Color.-In general the color so closely resembles that of Sciurus saturatus as to need no detailed description. On comparison of the two series the red of the underparts is seen to be less bright than in the Mansalar squirrel, and the pale element in the grizzle of the upperparts less yellow, though so far as possibility of description is concerned the colors are essentially the same. The most tangible difference is in the amount of black in the tail. In the Pulo Bangkaru animal this shows no tendency to form a black pencil or dark lateral fringe, as in Sciurus saturatus.

Skull and teeth.-Both skull and teeth are smaller than in Sciums saturatus or S. vittatus, but I can deteet no differences in form.

Measurements. - External measurements of type: Total length, 375; head and body, 200; tail vertebræ, 175; hind foot, 46 (43). Average of seven adults from the type locality: Total length, 387 (372-400); head and body, 207 (192-220); tail vertebræ, 181 (170-195); hind foot, 47.6 (46-49); hind foot without claws, 44.3 (43-46). For details see table, page 456 .

a Measurements in parentheses are those of an adult female Sciurus vittatus from Tapanuli Bay, Sumatra (No. 114518). 
Cranial measurements of type: Greatest length, 49.4 (52); basal length, 43 (43.6); basilar length, 40.4 (40); length of nasals, 15 (16.4); breadth of both nasals together anteriorly, 7.4 (7.4); distance from front of nasal to back of frontal, 25 (27.6); diastema, 11.6 (11.6): least interorbital breadth, 18 (18); zygomatic breadth, 29 (30); mandible, 32 (32.4); maxillary tooth row (aiveoli), 9 (9.6); mandibular tooth row (alveoli), 9.8 (10).

Specimens examined.-Eight, all from the type locality.

Remarks.-The specimens of this squirrel show no noteworthy variations.

SCIURUS UBERICOLOR, new species.

Type--Adult female (skin and skull), Cat. No. 114373, U.S.N.M. Collected on Pulo Tuangku, Banjak Islands, February 5, 1902, by Dr. W. L. Abbott. Original number, 1517.

Characters.-In general appearance like Sciums saturatus and S. pretiosus, but red of underparts darker and duller than in either and median line of belly frequently blackish; tail not distinctly darker than back; outer lateral stripe reduced in both length and width; size nearly as in S. saturatus.

Color.-The general color is closely similar to that of Sciumes saturatus and $S$. pretiosus, but the tone of the upperparts is lighter than in the former and more red than in the latter. Tail more coarsely grizzled than back, but the general effect scarcely darker. Outer lateral stripe of the same dull color as in the related forms, but its length usually less and its width generally not more than half as great (about $5 \mathrm{~mm}$. at middle in type). Underparts a duller red than in the related species, this due chiefly to the darker bases of the hairs. Along median line the dark bases increase sufficiently to form a distinct median dusky stripe in some specimens (including the type). The black lateral stripe tends to extend its inner margin in the same manner. Skull and teeth.-The skull and teeth are essentially like those of Sciurus saturatus.

Measurements. - External measurements of type: Total length, 405; head and body, 215; tail vertebræ, 195; hind foot, 51 (48). Average of seven specimens from the type locality; total length, 389 (345-415); head and body, 215 (205-225); tail vertebræ, 180 (170-210); hind foot, 49.3 (46-51); hind foot without claws, $45.9(43-48)$. For detalls see table, page 456 .

Cranial measurements of type: Greatest length, 52; basal length, 44 ; basilar length, 41.4; length of nasals, 17; breadth of both nasals together anteriorly, 7 ; distance from front of nasal to back of frontal, 38; diastema, 13; least interorbital breadth, 19; zygomatic breadth, 34; mandible, 34; maxillary toothrow (alveoli), 9.6; mandibular toothrow (alveoli), 9.8.

Specimens examined. - Nine, all from the type locality. 
Remarks.-While Sciurus ubericolor is darker beneath than in either of the two related forms, its upper parts are not as dark as in S. saturatus and the tail is much less suffused with black. The reduction of the pale lateral stripe easily distinguishes it from its allies.

Measurements of squirrels of the Sciurus notatus group.

\begin{tabular}{|c|c|c|c|c|c|c|c|c|}
\hline Name. & Locality. & Number. & Sex. & $\begin{array}{c}\text { Total } \\
\text { length. }\end{array}$ & $\begin{array}{l}\text { Head } \\
\text { and } \\
\text { body. }\end{array}$ & Tail. & $\begin{array}{l}\text { Hind } \\
\text { foot. }\end{array}$ & $\begin{array}{l}\text { Hind } \\
\text { foot } \\
\text { with- } \\
\text { out } \\
\text { claws. }\end{array}$ \\
\hline Sciurus albescens.... & Loh Sidoh Bay... & 114154 & Male adult.... & $\mathrm{mm}_{343}$ & $\begin{array}{l}m m . \\
193\end{array}$ & $\begin{array}{l}m m . \\
150\end{array}$ & $\mathrm{~mm}_{46}$ & $m_{42}$ \\
\hline $\begin{array}{l}\text { Do } \ldots \ldots \ldots \ldots \ldots \\
\text { Do } \ldots \ldots \ldots \ldots\end{array}$ & ..... do ........... & 114155 & .... do ........ & 350 & 190 & 160 & 45 & 41.4 \\
\hline $\begin{array}{l}\text { Do } \ldots \ldots \ldots \ldots \ldots \\
\text { Do } \ldots \ldots \ldots \ldots \ldots\end{array}$ & ..... do $\ldots . . . .$. & 114157 & ...... do. & 390 & 200 & 190 & 47 & 44 \\
\hline (n....... & …. do $\ldots . . . . . . .$. & 114158 & $\ldots$ do $\ldots$....... & 370 & 195 & 175 & 46 & 42 \\
\hline …… & $\mid \begin{array}{l}\ldots \\
\ldots \ldots \text { do } \ldots \ldots \\
\ldots\end{array}$ & $\begin{array}{l}114156 \\
114159\end{array}$ & Female adult. & 350 & 170 & 180 & 46 & 42 \\
\hline $\begin{array}{l}\text { Do .............. } \\
\text { Sciurus vittatus..... }\end{array}$ & Tajanulo . Bay.... & $\begin{array}{l}114159 \\
114518\end{array}$ & $\ldots$.... do $\ldots . .$. & $\begin{array}{l}373 \\
405\end{array}$ & & $\begin{array}{l}170 \\
185\end{array}$ & $\begin{array}{l}47 \\
48\end{array}$ & 43.4 \\
\hline $\begin{array}{r}\text { Sciurus vittatus...... } \\
\text { Do } . . . . . . . . . . .\end{array}$ & Tapanum bay..... & $\begin{array}{r}114518 \\
-114522\end{array}$ & $\begin{array}{l}\ldots . . \text { do } \ldots \\
\ldots . . \text { do } \ldots\end{array}$ & $\begin{array}{l}405 \\
397\end{array}$ & $\begin{array}{l}220 \\
200\end{array}$ & $\begin{array}{l}185 \\
197\end{array}$ & $\begin{array}{l}48 \\
50\end{array}$ & $\begin{array}{l}45 \\
47\end{array}$ \\
\hline Do $\ldots \ldots$ & ...... do ........... & 114523 & ....... do & 398 & 206 & 192 & 47 & $\begin{array}{l}47 \\
43\end{array}$ \\
\hline 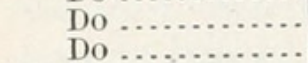 & ..... do........ & 114524 & ..do. & 390 & 190 & 200 & 48 & 45 \\
\hline $\begin{array}{l}\text { Do } \ldots \ldots \ldots \ldots \\
\text { Do } \ldots \ldots \ldots \ldots\end{array}$ & .....do do ........... & 114525 & ..... do & 385 & 205 & 180 & 48 & 45 \\
\hline $\begin{array}{l}\text { Do } \ldots \ldots \ldots \ldots \ldots \\
\text { Do } \ldots \ldots \ldots \ldots\end{array}$ & ..... do $\ldots . . . .$. & 114526 & ‥do $\ldots . . . .$. . & $\begin{array}{l}380 \\
30^{2}\end{array}$ & 215 & 165 & 48 & 45 \\
\hline $\begin{array}{l}\text { Do : } \\
\text { Do : }\end{array}$ & ..... do. & $\begin{array}{l}114519 \\
114520\end{array}$ & $\begin{array}{l}\text { Male adult..... } \\
\ldots . . \text { do ......... }\end{array}$ & $\begin{array}{l}393 \\
395\end{array}$ & $\begin{array}{l}208 \\
210\end{array}$ & $\begin{array}{l}185 \\
185\end{array}$ & $\begin{array}{l}48 \\
50\end{array}$ & $\begin{array}{l}46 \\
47\end{array}$ \\
\hline Do $\ldots \ldots \ldots \ldots$ & $\begin{array}{l}\ldots \\
\ldots \ldots \text { do } \\
\ldots\end{array}$ & 114521 & ..... do....... & 380 & 200 & $\begin{array}{l}180 \\
180\end{array}$ & $\begin{array}{l}50 \\
48\end{array}$ & 44 \\
\hline Sciurus saturatus... & Pulo Mansalar.. & 114627 & ..... do .. & 411 & 221 & 190 & $\begin{array}{l}10 \\
52\end{array}$ & 48.4 \\
\hline Do...$\cdots$ & ..... do........ & 114628 & ..... do ......... & 400 & 220 & 180 & 51 & 48 \\
\hline $\begin{array}{l}\text { Do } \\
\text { Do }\end{array}$ & ..... do ........... & a 114629 & Female adult. & 400 & 215 & 185 & 51 & 47 \\
\hline $\begin{array}{l}\text { Do } \ldots \\
\text { Do } \ldots\end{array}$ & ..... do ..... & 114630 & ..... do .......... & 390 & 200 & 190 & 52 & 49 \\
\hline $\begin{array}{l}\text { Do ............. } \\
\text { Sciurus ubericolor.. }\end{array}$ & ....do do ........... & $\bullet 114631$ & $\ldots \ldots$ do $\ldots \ldots$. & 375 & 185 & 190 & 51 & $\begin{array}{l}47.4 \\
45\end{array}$ \\
\hline $\begin{array}{r}\text { Sciurus ubericolor... } \\
\text { Do ............... }\end{array}$ & Pulo Tuangku.. & 114366 & Maleadult.... & $\begin{array}{l}382 \\
400\end{array}$ & $\begin{array}{l}207 \\
220\end{array}$ & $\begin{array}{l}175 \\
180\end{array}$ & $\begin{array}{l}48 \\
50\end{array}$ & $\begin{array}{l}45 \\
47\end{array}$ \\
\hline $\begin{array}{l}\text { Do } \ldots \ldots \ldots \\
\text { Do } \ldots \ldots\end{array}$ & $\ldots$ do $\ldots \ldots \ldots$ & $\begin{array}{l}114367 \\
114369\end{array}$ & 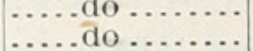 & $\begin{array}{l}400 \\
375\end{array}$ & 205 & 170 & $\begin{array}{l}00 \\
46\end{array}$ & $\begin{array}{l}41 \\
43\end{array}$ \\
\hline Do $\ldots \ldots \ldots \ldots$ & $\begin{array}{l}\ldots \\
\ldots \ldots \text { do } \ldots \ldots\end{array}$ & 114371 & .......do. & 395 & 210 & 185 & 50 & 46 \\
\hline Do ............ & ...... do ........... & 114368 & Female young & 310 & 175 & 135 & 47 & 39 \\
\hline Do $\ldots \ldots \ldots \ldots$ & .... do ............ & 114370 & Female adult. & 345 & 225 & c 120 & 49 & 45 \\
\hline Do ... & ..... do ........... & 114372 & ...... do .......... & b 415 & $b 205$ & $b 210$ & 50 & 46 \\
\hline Do ... & ..... do ... & a 114373 & ..... do. & 410 & 215 & 195 & 51 & 48 \\
\hline Do ........... & $\ldots \ldots$ do $\ldots . . . \ldots .$. & 114374 & $\ldots$. do $\ldots . .$. & 415 & 225 & 190 & 51 & 47 \\
\hline Sciurus pretiosus. & Pulo Bangkaru. & 114318 & Male adult. & 375 & 205 & 170 & 48 & \\
\hline Do..... & ..... do ............ & 114320 & ..... do ...... & 400 & 205 & 195 & 48 & 45 \\
\hline Do .... & ..... do ........... & 114321 & .....do. & 372 & 192 & 180 & 47 & 44 \\
\hline Do ... & ..... do ........... & 114322 & ...... do . & 390 & 210 & 180 & 47 & 43 \\
\hline Do ... & do $\ldots$ & 114323 & ......do. & c 335 & 210 & $c 125$ & 48 & 45 \\
\hline Do ... & do . & 114324 & $\ldots \ldots$ do $\ldots$. $\ldots$. & 400 & 215 & 185 & 48 & 44.4 \\
\hline Do ............. & ..... do ......... & 114319 & Female adult. & 400 & 220 & 180 & 49 & 45 \\
\hline Do ............. & ..... do .......... & a 114325 & ..... do .......... & 375 & 200 & & & \\
\hline
\end{tabular}

a Type.

$b$ Estimated from dry skin.

Tail injured.

SCIURUS EREBUS, new species.

Type-Adult female (skin and skuli). Cat. No. 114537, U.S.N.M. Collected at Tapanuli Bay, northwestern Sumatra, March 17, 1902, by Dr. W. L. Abbott. Original number, 1653.

Characters. - Similar to the Bornean Sciurus pluto Gray, but larger, red area on legs more extensive, and pale lateral stripe completely obliterated.

Color.-Under parts and inner surface of limbs bright chestnut (lighter and more red than that of Ridgway); elsewhere glossy black. On cheeks, feet, and outer surface of front legs the black is slightly grizzled with whitish and red, and along flanks and thighs a few hairs bear a single whitish annulation rather less than $1 \mathrm{~mm}$. in length, but these markings are lost in the general black effect, except on very 
close inspection. The black of cheeks extends under chin across an area about $10 \mathrm{~mm}$. in width. On front legs the red area is much wider than the black, and on inner side it extends to naked surface of palm. In $S$. pluto the black area is the more extensive, and it encircles the wrist just above palm. On hind legs the same differences occur. The red area is much wider in the Sumatran than in the Bornean form, and it usually extends to edge of naked sole, though occasionally the black narrowly encircles ankle.

Skull and teeth.-The skull and teeth so closely resemble those of Sciurus pluto that I can detect no tangible differences.

Measurements.-External measurements of type: Total length, 485; head and body, 260; tail vertebræ, 225; hind foot, 58 (53). Average of twelve adults from the type locality: Total length, 473 (430-498); head and body, 247 (230-263); tail vertebræ, 227 (200-240); hind foot, $58.1(57-59)$; hind foot without claws, $53(51-55)$. For details, see table, page 457 .

Cranial measurements of type: Greatest length, $58(56) ;^{a}$ basal length, 50 (49); basilar length, 46.6 (46); diastema, 13.6 (13.6); length of nasals, 17.8 (16.6); greatest breadth of both nasals together, 8.8 (8.6); least interorbital breadth, 23 (22.6); zygomatic breadth, 34.6 (34); mandible, 37 (37); maxillary toothrow (alveoli), 11 (11); mandibular toothrow (alveoli), 11 (11.4).

Specimens examined.-Twelve, all from Tapanuli Bay.

Remarks.-While Scinms erebus rather closely resembles S. pluto, it is readily distinguishable from the Bornean animal by its greater size and by the absence of the pale lateral stripe. There is not the slightest indication of this stripe in any of the twelve skins, while in each of five specimens of Sciurus pluto it may be easily traced. The difference in extent of the red on the legs is a less constant character.

Measurements of Sciurus erebus.

\begin{tabular}{|c|c|c|c|c|c|c|c|}
\hline Locality. & Number. & Sex. & $\begin{array}{c}\text { Total } \\
\text { length. }\end{array}$ & $\begin{array}{l}\text { Head } \\
\text { and } \\
\text { body. }\end{array}$ & $\begin{array}{c}\text { Tail } \\
\text { verte- } \\
\text { bræ. }\end{array}$ & $\begin{array}{l}\text { Hind } \\
\text { foot. }\end{array}$ & $\begin{array}{l}\text { Hind } \\
\text { foot } \\
\text { with- } \\
\text { out } \\
\text { claws. }\end{array}$ \\
\hline 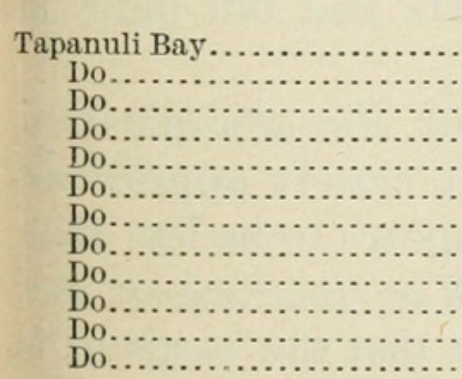 & $\begin{array}{r}114530 \\
114531 \\
114533 \\
114534 \\
114539 \\
114541 \\
114532 \\
114535 \\
114536 \\
a 114537 \\
114538 \\
114540\end{array}$ & 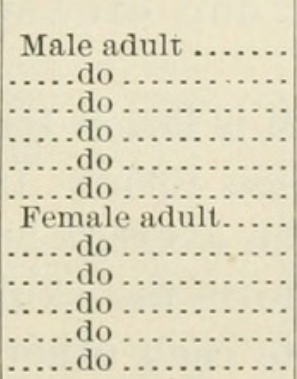 & $\begin{array}{r}m m . \\
480 \\
483 \\
430 \\
455 \\
470 \\
465 \\
498 \\
480 \\
480 \\
485 \\
485 \\
470\end{array}$ & $\begin{array}{r}m m . \\
250 \\
250 \\
230 \\
240 \\
235 \\
245 \\
263 \\
245 \\
255 \\
260 \\
245 \\
245\end{array}$ & $\begin{array}{l}m m . \\
230 \\
233 \\
200 \\
215 \\
235 \\
220 \\
235 \\
235 \\
225 \\
225 \\
240 \\
225\end{array}$ & $\begin{array}{r}m m . \\
58 \\
57 \\
58 \\
57 \\
59 \\
58 \\
59 \\
59 \\
58 \\
58 \\
59 \\
57\end{array}$ & $\begin{array}{r}m m . \\
53 \\
52 \\
54 \\
51 \\
53 \\
53 \\
55 \\
55 \\
53 \\
52 \\
53 \\
52\end{array}$ \\
\hline
\end{tabular}

a Type.

a Measurements in parentheses are those of an adult male Sciurus pluto from British North Borneo (No. 34941). 
RHINOSCIURUS LATICAUDATUS (Müller and Schlegel).

1839-1844. Sciurus laticaudatus Müller and Schlegel, Verhandel. over de natuurlijke Geschiedenis der Nederl. overzeesche bezittingen, p. 100; Pontianak, Western Borneo.

An adult female was taken on Pulo Tuangku, Banjak Islands, February 15, 1902. Total length, 360; head and body, 230; tail vertebræ, 130; hind foot, 46 (44). Skull: Greatest length, 59; basal length, 52; basilar length, 49.4; palatal length, 31; diastema, 17; length of nasals, 21 ; breadth of both nasals together anteriorly, 6 ; least interorbital breadth, 13; zygomatic breadth, 28.6; mandible, 35.6; maxillary toothrow (alveoli), 12; mandibular toothrow (alveoli), 10.4. " Uterus contained one embryo the size of a pea. Mammæ, 4."

\section{FAMILY MURID E.}

MUS SIMALURENSIS, new species.

Type-Adult female (skin and skull), Cat. No. 114216, U.S.N.M. Collected on Simalur Island December 14, 1901, by Dr. W. L. Abbott. Original number, 1372.

Characters.-Like Mus pannosus of the Butang Islands, but rather smaller; fur shorter and less coarse; color darker and less yellowish; teeth smaller; mammæ 10, as in other members of the group.

Fur.-The fur is rather close and fine in texture, much more so than that of Mus pannosus, though it contains many grooved bristles. These, however, are scarcely more stiff than the longer terete hairs. At middle of back the body of the fur is about $14 \mathrm{~mm}$. in length, the scattered long hairs exceeding this by about $6 \mathrm{~mm}$. These long hairs show no distinct tendency to increase in length on rump and lumbar region.

Color.-Back and sides a moderately coarse, but not very conspicuous grizzle of black and dull ochraceous buff, the former a little in excess on back, the latter distinctly so on sides, and tips of bristles and longer hairs with metallic iridescence. Underparts buff, rather lighter than that of Ridgway, and somewhat clouded by gray along median line of chest. Feet dull brownish. Ears and tail uniform dark brown.

Skull and teeth.-The skull is larger than that of Mus alexandrinus, though of essentially the same form. In size it closely approaches that of Mus pannosus, but the average length appears to be less than in the Butang animal. In form the skulls of Mus simalurensis and M. pannosus closely resemble each other, except that the rostrum is more slender in the Simalur rat and the incisive foramina are longer, narrower, and more nearly parallel-sided. Teeth as in Mus pannosus, but smaller.

Measurements.-External measurements of type: Total length, 402: 
head and body, 204; tail vertebræ, 198; hind foot, 42.4 (40). Average of 5 adults from the type locality: Total length, 388 (377-402); head and body, 206 (200-213); tail vertebræ, 182 (176-198); hind foot, 40.4 (39.2-42.2); hind foot without claws, $37.8(36-40)$. For details, see table, page 459 .

Cranial measurements of type: Greatest length, $47.4(46) ;^{a}$ basal length, 41.8 (40); basilar length, 39 (37); diastema, 13 (12.4); length of incisive foramen, 9 (8); combined breadth of incisive foramina, 3.4 (3.8); length of nasals, 18 (17.6); greatest breadth of both nasals together, $5.2(5.6)$; zygomatic breadth, 23 (22); least interorbital breadth, 7.4 (7); breadth of brain case above roots of zygomata, 17 (17); depth of brain case at front of basioccipital, 12 (11.4); frontopalatal depth at posterior extremity of nasals, 11.8 (11.6); mandible, 28 (28); maxillary tooth row (alveoli), 8 (8.4), mandibular tooth row (alveoli), 8 (8.4).

Specimens examined.-Thirty-two from the following localities: Simalur Island (main island), 8 (2 in alcohol); Simalur Island (Pulo Siumat), 6 (1 skull without skin); Pulo Lasia, 16 (3 in alcohol; 3 skulls without skins); Pulo Babi, 2 (skulls only).

Remarks.-This is a well-defined member of the Mus rattus group, most closely related, apparently, to the form occurring on the Butang Islands on the opposite side of Sumatra. Its presence on Simalur and the neighboring islands may have been originally due to human agency, though there is no reason to suppose that the animal has been introduced within historic times.

Measurements of Mus simalurensis.

\begin{tabular}{|c|c|c|c|c|c|c|c|}
\hline Locality. & Number. & Sex. & $\begin{array}{c}\text { Total } \\
\text { length. }\end{array}$ & $\begin{array}{l}\text { Head } \\
\text { and } \\
\text { body. }\end{array}$ & Tail. & $\begin{array}{l}\text { Hind } \\
\text { foot. }\end{array}$ & $\begin{array}{l}\text { Hind } \\
\text { foot } \\
\text { with- } \\
\text { out } \\
\text { claws. }\end{array}$ \\
\hline 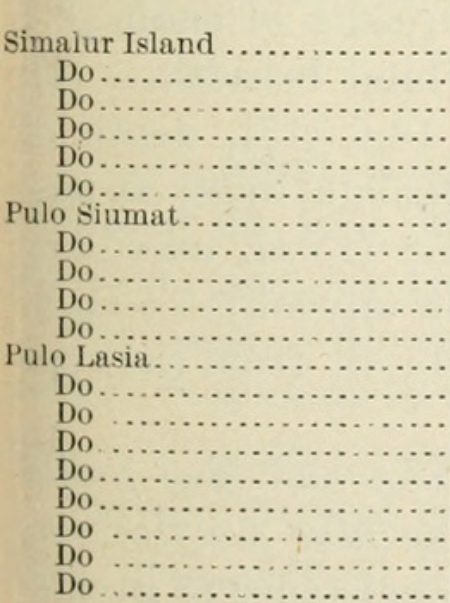 & $\begin{array}{r}114214 \\
114215 \\
114213 \\
a 114216 \\
114217 \\
114218 \\
114221 \\
114225 \\
114222 \\
1142223 \\
114224 \\
114257 \\
114260 \\
114261 \\
114262 \\
114253 \\
114254 \\
114255 \\
114256 \\
114258\end{array}$ & 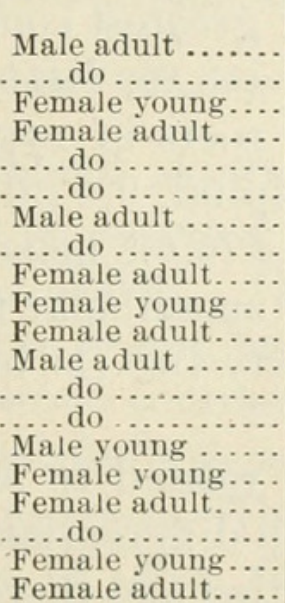 & $\begin{array}{r}m m . \\
389 \\
393 \\
357 \\
402 \\
380 \\
377 \\
415 \\
413 \\
383 \\
342 \\
375 \\
433 \\
417 \\
411 \\
385 \\
356 \\
456 \\
437 \\
370 \\
445\end{array}$ & $\begin{array}{r}m m . \\
213 \\
211 \\
190 \\
204 \\
201 \\
200 \\
224 \\
212 \\
204 \\
172 \\
198 \\
225 \\
205 \\
210 \\
178 \\
176 \\
231 \\
225 \\
182 \\
227\end{array}$ & $\begin{array}{r}m m . \\
176 \\
182 \\
167 \\
198 \\
179 \\
177 \\
191 \\
201 \\
179 \\
170 \\
177 \\
208 \\
212 \\
201 \\
207 \\
180 \\
225 \\
212 \\
188 \\
218\end{array}$ & $\begin{array}{l}m m . \\
39 \\
40 \\
38 \\
42.2 \\
40 \\
41 \\
42 \\
42.4 \\
40 \\
39.6 \\
41.4 \\
43 \\
41 \\
42.4 \\
42 \\
40 \\
42.2 \\
40.4 \\
40.4 \\
43.4\end{array}$ & $\begin{array}{c}m m . \\
36 \\
36 \\
35 \\
40 \\
38 \\
39 \\
38.6 \\
40 \\
38 \\
37 \\
38.4 \\
39.4 \\
39 \\
40 \\
40 \\
38 \\
40 \\
39 \\
39 \\
41.2\end{array}$ \\
\hline
\end{tabular}

a Type.

${ }^{a}$ Measurements in parentheses are those of an adult female Mus pannosus (No. 104115) from Pulo Adang, Butang Islands. 
MUS SURDUS, new species.

Type.-Adult male (skin and skull), Cat. No. 114184, U.S.N.M. Collected on Simalur Island December 11, 1901, by Dr. W. L. Abbott. Original number, 1359.

Characters. - Similar to Mus concolor Blyth and Mus pullus Miller, but larger and paler.

Fur and external characters in general.-The fur, tail, ears, feet, etc., are as in Mus concolor and Mus pullus. Mammae, i. 2-2, p. 2-2=8.

Color.-Back and sides a coarse, inconspicuous grizzle of dull ochraceous buff and blackish brown, the former slightly in excess on back and distinctly predominating on sides. Underparts and inner surface of limbs dirty white, tinged with cream buff. In the type there is a fairly well defined line of demarcation between the color of sides and that of belly. This contrast, though not always so conspicuous, is invariably more noticeable than in the type of Mus pullus or the two specimens of Mus concolor that I have examined. Ears blackish brown externally, lightly sprinkled with fine, silvery hairs internally. Feet dirty whitish.

Skull and teeth.-Both skull and teeth are noticeably larger than in Mus concolor and Mus pullus, but I can detect no tangible difference in form.

Measurements.-External measurements of type: Total length, 265; head and body, 127; tail vertebræ, 138; hind foot, 28 (26). Average of 21 adults from the type locality: Total length, 268 (238-324); head and body, 130 (112-143); tail vertebræ, 139 (119-182); hind foot, 27 (26-28.2); hind foot without claws, 25.4 (24-27). For details see table, page 461.

Cranial measurements of type: Greatest length, $33(30) ;^{a}$ basal length, 28.6 (26); basilar length, 26 (23); diastema, 8.8 (8); length of incisive foramen, $6.4(5.4)$; combined breadth of incisive foramina, 2.8 (2); length of nasals, 12 (11); greatest combined breadth of nasals, 3.4 (3); zygomatic breadth, 15.4 (13.6); least interorbital breadth, 5 (4); breadth of brain case above roots of zygomata, 13.6 (13); depth of brain case at front of basioccipital, $9.6(9)$; frontopalatal depth at posterior extremity of nasals, 7.4 (6.6); mandible, 18.8 (15.4); maxillary tooth row (alveoli), 5.6 (4.6); mandibular tooth row (alveoli), 5.6 (4.6).

Specimens examined. - Thirty-two (11 in alcohol), all from the type locality.

Remarks. - Though closely related to Mus concolor and Mus pullus this species appears to be well differentiated. Like Mus simalurensis it probably owes its introduction and therefore its existence to prehistoric man.

a Measurements in parantheses are those of the type of Mus pullus. 
at surface of the gray (very nearly Ridgeway's No. 6) of the under fur. The longer hairs show a distinct bluish luster. Under parts and inner surface of legs gray (about Ridgeway's No. 6) faintly washed with grayish buff, the contrast between the color of this region and that of sides very slight. Head similar to back, but grizzle more fine. Feet dull, dark brown. Ears and tail uniform blackish.

Skull and teeth. - The skull and teeth so closely resemble those or Mus firmus that I can find no tangible characters by which to dis. tinguish them.

Measurements.-External measurements of type: Total length, 490 head and body, 243; tail vertebræ, 247; hind foot, 47 (44). Averagt of 5 specimens from the type locality: Total length, 457 (400-497) head and body, 227 (200-251); tail vertebræ, 230 (200-252); hind foot $46.4(45-48)$; hind foot without claws, $43.6(42-45)$. For details see table, page 462 .

Cranial measurements of type: Greatest length, $53(53) ;^{a}$ basa length, 46.4 (46); basilar length, 43.6 (43); length of nasals, 21 (21.4) greatest combined breadth of nasals, 5.8 (5.6); diastema, 15 (15) zygomatic breadth, $26(27)$; least interorbital breadth, 8 (8); depth 0 brain case at front of basioccipital, 13 (13); frontopalatal depth at pos terior extremity of nasals, 12.4 (13); mandible, 31.4 (32.4); maxillar: tooth row (alveoli), 9 (9.4); mandibular tooth row (alveoli), 9.6 (10).

Specimens examined. - Seven (one skull without skin), all from Pul. Mansalar.

Remarks. - The distinctness of this species from the Mus firmus o the near-by mainland is unquestionable.

Measurements of Mus firmus and Mus domitor.

\begin{tabular}{|c|c|c|c|c|c|c|c|c|}
\hline Name. & Locality. & Number. & Sex. & $\begin{array}{c}\text { Total } \\
\text { length. }\end{array}$ & $\begin{array}{l}\text { Head } \\
\text { and } \\
\text { body. }\end{array}$ & Tail. & $\begin{array}{l}\text { Hind } \\
\text { foot. }\end{array}$ & $\begin{array}{c}\text { Hinc } \\
\text { foot } \\
\text { with } \\
\text { out } \\
\text { claws }\end{array}$ \\
\hline 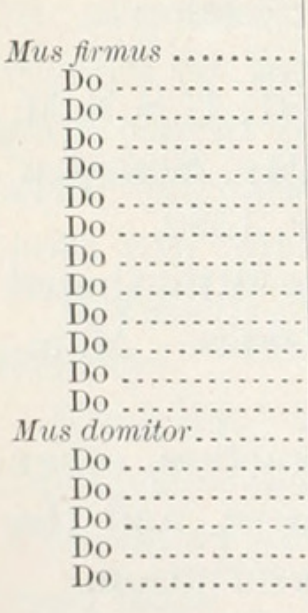 & 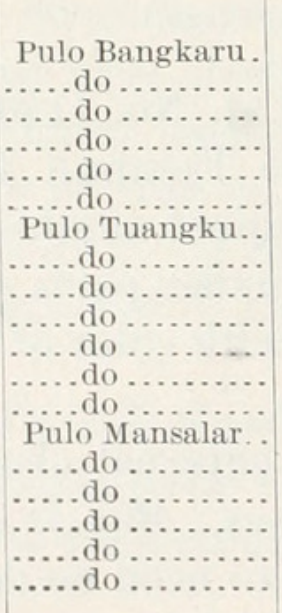 & $\begin{array}{r}114285 \\
114286 \\
114287 \\
114288 \\
114289 \\
114290 \\
114378 \\
114380 \\
114382 \\
114384 \\
114379 \\
114381 \\
114383 \\
114620 \\
a 114621 \\
114622 \\
114623 \\
114624 \\
114625\end{array}$ & 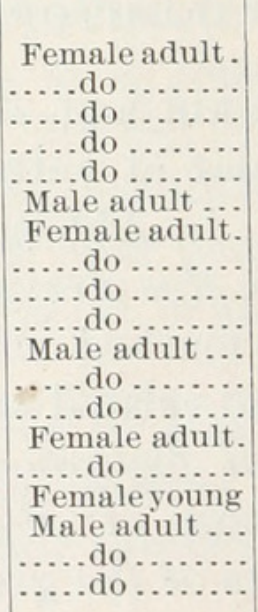 & $\begin{array}{r}m m . \\
435 \\
441 \\
408 \\
440 \\
411 \\
412 \\
457 \\
435 \\
482 \\
485 \\
458 \\
487 \\
530 \\
400 \\
490 \\
384 \\
485 \\
413 \\
497\end{array}$ & $\begin{array}{r}m m . \\
232 \\
233 \\
216 \\
230 \\
218 \\
212 \\
220 \\
222 \\
242 \\
245 \\
228 \\
249 \\
270 \\
200 \\
243 \\
185 \\
233 \\
207 \\
251\end{array}$ & $\begin{array}{r}m m . \\
203 \\
208 \\
192 \\
210 \\
193 \\
200 \\
237 \\
213 \\
240 \\
240 \\
230 \\
238 \\
260 \\
200 \\
247 \\
199 \\
252 \\
206 \\
246\end{array}$ & $\begin{array}{l}\mathrm{mm} . \\
45 \\
46 \\
43.4 \\
45 \\
44 \\
46 \\
50 \\
46.4 \\
48 \\
47 \\
49 \\
48 \\
50 \\
46 \\
47 \\
42 \\
48 \\
45 \\
46\end{array}$ & $\mathrm{~mm}$. \\
\hline
\end{tabular}

a Type. 


\section{MUS FREMENS Miller.}

1902. Mus fremens Mrller, Proc. Acad. Nat. Sci. Philadelphia, 1902, p. 154, March, 1902; Sinkep Island, off east coast of Sumatra.

Twenty-four specimens, from the following localities: Pulo Tuangku, 7 (2 skulls without skins); Pulo Bangkaru, 1; Pulo Mansalar, 7 (1 skull without skin); Tapanuli Bay, 9 (5 skulls without skins). This series shows variation in both size and color, but for the present I prefer to refer it as a whole to Mus fremens. None of the skins show any close approach to the bright colors of Mus vociferans. For measurements, see table.

Measurements of Mus fremens.

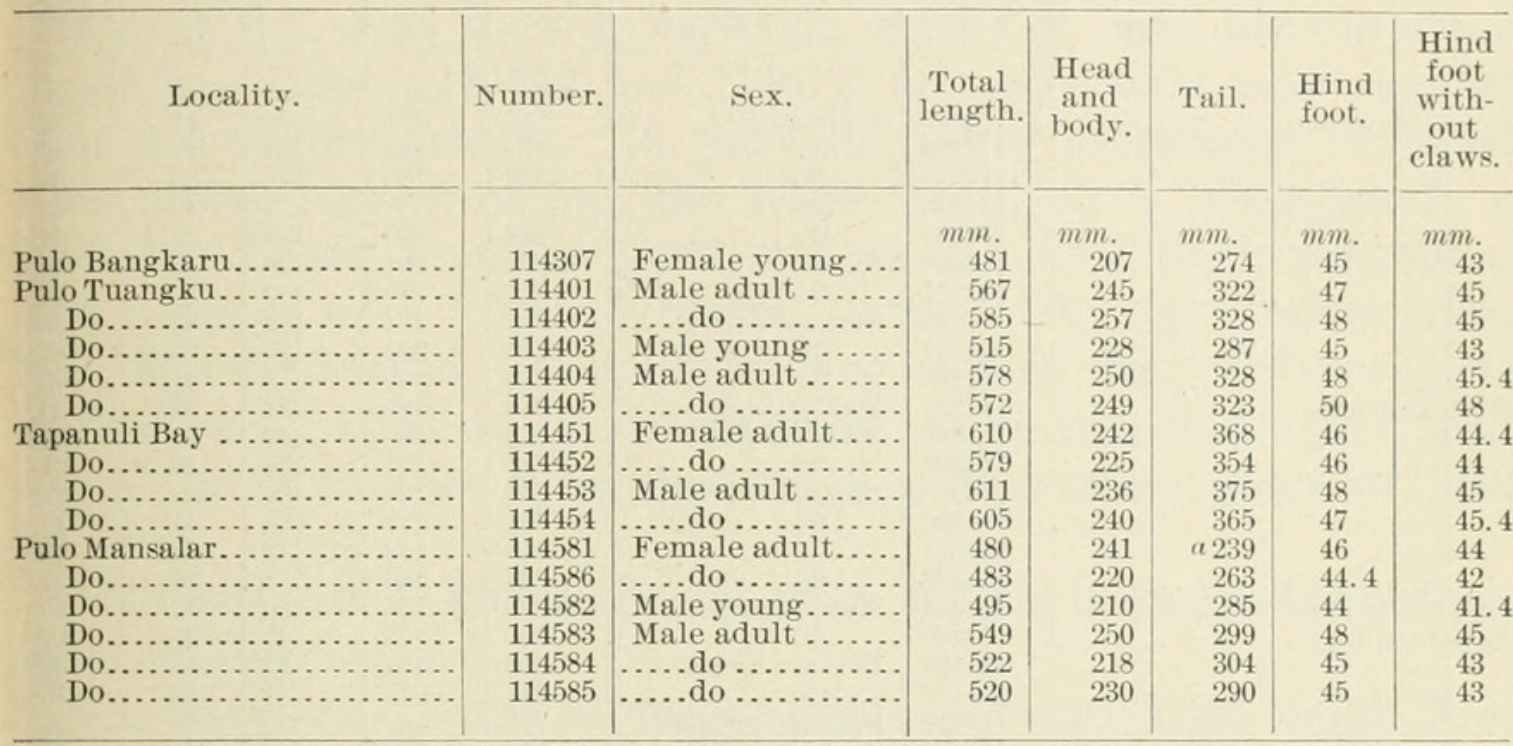

$a$ Tail damaged.

\section{MUS ASPER Miller.}

1900. Mus asper Miller, Proc. Biol. Soc. Washington, XIII, April 21, 1900, p. 145; Trong, Lower Siam.

An adult male (skin and skull) and female (skull only) from Pulo Tuangku, Banjak Islands, and an adult female (in alcohol) from Tapanuli Bay. These specimens so closely resemble Mus asper that without further material I am unable to distinguish them. The male from Pulo Tuangku measures: Total length, 249; head and body, 140; tail, 109; hind foot, 29.6 (28). The female from Tapanuli Bay measures: Total length, 210; head and body, 105; tail, 105; hind foot, 27 (26).

\section{MUS LINGENSIS Miller.}

1900. Mus lingensis Mrller, Proc. Washington Acad. Sci., II, August 20, 1900, p. 206; Linga Island, off east coast of Sumatra.

Forty specimens, as follows: Pulo Bangkaru, 15 ( 1 in alcohol, 4 skulls without skins); Pulo Tuanku, 12 (2 in alcohol, 3 skulls without skins); Tapanuli Bay, Sumatra, 13 (1 in alcohol, 7 skulls without skins). For measurements, see table, page 464 . 
Many of the skins are in fresh, unworn pelage, a stage in which they differ almost as strongly from the bright-colored Mus surifer of the Malay Peninsula as was the case with the original specimens taken in midsummer. In fact, the general color of the rats of this group appears to be only slightly affected by abrasion of the fur. In the six specimens from Tapanuli Bay there is no indication of a dark collar. The collar is present in about half the skins from the Banjak Islands, though in none is it developed as in the Pulo Mansalar form.

Measurements of Mus lingensis.

\begin{tabular}{|c|c|c|c|c|c|c|c|}
\hline Locality. & Number. & Sex. & $\begin{array}{c}\text { Total } \\
\text { length. }\end{array}$ & $\begin{array}{l}\text { Head } \\
\text { and } \\
\text { body. }\end{array}$ & Tail. & $\begin{array}{l}\text { Hind } \\
\text { foot. }\end{array}$ & $\begin{array}{l}\text { Hind } \\
\text { foot } \\
\text { with- } \\
\text { out } \\
\text { claws. }\end{array}$ \\
\hline Pulo Bangkaru............ & 114292 & Male adult . & $\mathrm{mm}_{34}$ & $\begin{aligned} & m m \\
& 191\end{aligned}$ & ${ }_{153}$ & $m_{41}^{m m}$ & $\begin{array}{r}m m . \\
39\end{array}$ \\
\hline Do....................... & 114294 & .... do ........ & 372 & 205 & 167 & 42 & 39.4 \\
\hline${ }^{\prime} \ldots \ldots \ldots \ldots \ldots$ & 114295 & ..... do ........ & 328 & 180 & 148 & 39 & 36 \\
\hline $\begin{array}{l}\text { Do. } \\
\text { Do. }\end{array}$ & $\begin{array}{l}114296 \\
114299\end{array}$ & ...... do. & 358 & 300 & 158 & $\begin{array}{l}40 \\
394\end{array}$ & $\begin{array}{l}38 \\
374\end{array}$ \\
\hline (n)........ & 114300 & ....... do & b 332 & 204 & $b 128$ & $\begin{array}{l}39.4 \\
40\end{array}$ & $\begin{array}{l}37.4 \\
38\end{array}$ \\
\hline Do... & 114301 & ….. do $\ldots$......... & 332 & 180 & 152 & 39 & $\begin{array}{l}50 \\
37\end{array}$ \\
\hline 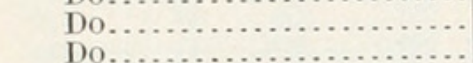 & 114293 & Female adult..... & 343 & 184 & 159 & 38.4 & 36 \\
\hline n........... & 114297 & ..... do ............ & $b 330$ & 200 & $b 130$ & 36.4 & 35.4 \\
\hline${ }^{\prime} \ldots \ldots \ldots \ldots \ldots, \ldots$ & 114298 & $\ldots \ldots$ do $\ldots$. & 380 & 205 & 175 & 41.6 & 40 \\
\hline 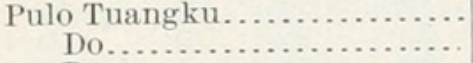 & 114387 & Male you & $\begin{array}{l}316 \\
330\end{array}$ & $\begin{array}{l}182 \\
183\end{array}$ & $\begin{array}{l}134 \\
147\end{array}$ & $\begin{array}{l}38.4 \\
39.2\end{array}$ & $\begin{array}{l}36 \\
36\end{array}$ \\
\hline 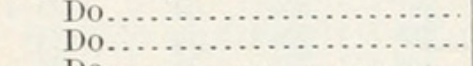 & $\begin{array}{l}114389 \\
114392\end{array}$ & 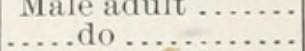 & $\begin{array}{l}300 \\
342\end{array}$ & $\begin{array}{l}183 \\
191\end{array}$ & 151 & $\begin{array}{l}39.2 \\
40.6\end{array}$ & $\begin{array}{l}36 \\
37\end{array}$ \\
\hline 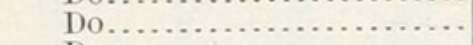 & 114388 & Female adult..... & 361 & 204 & 157 & 39 & 37 \\
\hline Do.................... & 114390 & ..... do $\ldots . . . . . .$. & 331 & 177 & 154 & 41 & 37.4 \\
\hline n.m. & 114391 & ...... do. & 340 & 192 & 148 & 39 & 36 \\
\hline Do........... & 114393 & $\ldots$. do . . & 334 & 186 & 148 & 39 & 37 \\
\hline Loh Sidoh Bay ........... & 114161 & Male young..... & 295 & 145 & 150 & 37 & 35 \\
\hline Tapanuli Bay ............ & 114438 & ..... do $\ldots \ldots \ldots$. & 330 & 173 & 157 & 39 & 37 \\
\hline 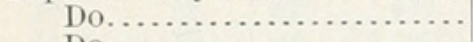 & 114436 & Female adult... & 320 & 167 & 153 & & 36.2 \\
\hline $\cos 25+5$ & 114437 & do & 394 & 213 & 181 & 39 & 36.4 \\
\hline Do. & 114439 & Female young.. & 315 & 162 & 153 & & 37 \\
\hline Do........ & 114440 & Female adult..... & 414 & 218 & 196 & 41.6 & 40 \\
\hline Linga Island ... & 101610 & Male adult ..... & 362 & 203 & 159 & 38 & 37 \\
\hline Do............. & 101612 & ..... do .......... & 400 & 216 & 184 & 43 & 42 \\
\hline Do. & a 101614 & ..... do ... & 387 & 216 & 171 & & 40.4 \\
\hline & 113044 & ..... do .. & 354 & 188 & 166 & 41 & 39 \\
\hline Do. & 113048 & ..... do .. & 389 & 219 & 170 & 43 & 41 \\
\hline & 113049 & ..... do. & 420 & 237 & 183 & 41 & 39.4 \\
\hline Do. & 113050 & ..... do ... & 383 & 201 & 182 & 39 & 36.4 \\
\hline Do. & 101611 & Female adult..... & 375 & 210 & 165 & 38 & 36 \\
\hline Do. & 113040 & $\ldots$. do $\ldots$. & 380 & 205 & 175 & 40 & 38 \\
\hline Do....... & 113042 & & a 310 & 220 & a 90 & 39.4 & 37 \\
\hline Do.................... & 113047 & ..... do ........ & 330 & 177 & 153 & & \\
\hline
\end{tabular}

Type--Adult female (skin and skull). Cat. No. 114590, U.S.N.M. Collected on Pulo Mansalar, off Tapanuli Bay, Sumatra, March 3, 1902 , by Dr. W. L. Abbott. Original number, 1587.

Characters.-In general similar to Mus lingensis, but darker; lower leg entirely tawny, and throat with broad cross-band of same color.

Fur and general external features.--The external characters, color excepted, agree so closely with those of Mus lingensis as to need no special description. The spines on the back are rather less coarsf than in the related species. 
Color.-Type: Back and sides tawny ochraceous, considerably paler than that of Ridgway, everywhere heavily clouded by the blackish brown of the spines and longer hairs. On middle of back the dark color is greatly in excess, but on sides the tawny-ochraceous slightly predominates. Crown and forehead like back; cheeks clear, dull, tawny-ochraceous. Outer surface of limbs tawny-ochraceous, paler than that of sides, and somewhat dulled by appearance at surface of slaty bases of hairs. The tawny-ochraceous completely encircles heel and wrist, extending up to middle of lower leg and forearm. Underparts dull white, distinctly marked with cream buff. Throat just in front of forelegs crossed by an ochraceous buff band about $25 \mathrm{~mm}$. in width. Feet dull whitish. Ears and tail blackish brown, the latter indistinctly whitish beneath and at tip.

Nine of the skins show no variation worthy of note, but the other three (Nos. 114611, 114612, and 114613) are so peculiar as to suggest their specific distinctness. In these the tawny-ochraceous is absent from median dorsal region, the whole of which is consequently a clear slaty brown from shoulders to base of tail, strongly contrasted with color of sides. Entire ventral surface dull, light, ochraceousbuff, slightly marked with whitish along median line. Otherwise as in the type. As these specimens show no peculiarities other than color, I think they are to be regarded as a dichromatic phase of Mus catellifer.

Skull and teeth.-The skull and teeth are not distinguishable from those of Mus lingensis.

Measurements.--External measurements of type: Total length, 348; head and body, 202; tail vertebræ, 146; hind foot, 40 (39). Average of nine specimens from type locality: Total length, 350 (309-398); head and body, 195 (176-221); tail vertebræ, 155 (133-177); hind foot, $41(40-43)$; hind foot without claws, $38.9(37.4-41)$. For details see table, page 466 .

Cranial measurements of type: Greatest length, $46(47.5) ;^{a}$ basal length, 39 (40.4); basilar length, 37 (37.5), diastema, 13 (13.4); length of incisive foramen, 7 (7); combined breadth of incisive foramina, f.4 (4); length of nasals, 17 (19); greatest combined breadth of nasals, 5 (5.4); zygomatic breadth, $20(20)$; least interorbital breadth $6.6(6.8)$; mandible, 25 (25.4); maxillary tooth row (alveoli), 7 (8); mandibular tooth row (alveoli), 7 (7.2).

Specimens examined.-Thirty-two (2 in alcohol; 18 skulls without skins), all from Pulo Mansalar.

$a$ Measurements in parentheses are those of the type of Mus lingensis.

Proc. N. M. vol. xxvi-02-32 
Measurements of Mus catellifer.

\begin{tabular}{|c|c|c|c|c|c|c|c|}
\hline Locality. & Number. & Sex. & $\begin{array}{c}\text { Total } \\
\text { length. }\end{array}$ & $\begin{array}{l}\text { Head } \\
\text { and } \\
\text { body. }\end{array}$ & Tail. & $\begin{array}{l}\text { Hind } \\
\text { foot. }\end{array}$ & $\begin{array}{c}\text { Hind } \\
\text { foot } \\
\text { with- } \\
\text { out } \\
\text { claws. }\end{array}$ \\
\hline 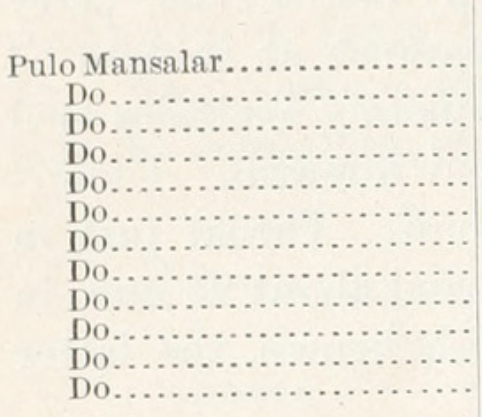 & $\begin{array}{r}114588 \\
114589 \\
a 114590 \\
114593 \\
114596 \\
114612 \\
114591 \\
114592 \\
114594 \\
114595 \\
114611 \\
114613\end{array}$ & 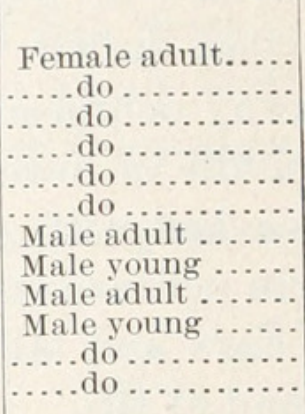 & $\begin{array}{r}m m . \\
b 322 \\
376 \\
348 \\
366 \\
333 \\
383 \\
338 \\
297 \\
398 \\
333 \\
328 \\
309\end{array}$ & $\begin{array}{r}m m . \\
220 \\
208 \\
202 \\
222 \\
177 \\
219 \\
183 \\
157 \\
221 \\
186 \\
179 \\
176\end{array}$ & \begin{tabular}{r|}
$m m$. \\
$a 102$ \\
168 \\
146 \\
144 \\
156 \\
164 \\
155 \\
140 \\
177 \\
147 \\
149 \\
133
\end{tabular} & $\begin{array}{r}m m_{.} \\
41 \\
40 \\
40 \\
38 \\
40 \\
41 \\
43 \\
40 \\
41 \\
42 \\
42 \\
40\end{array}$ & $\begin{array}{l}m m . \\
39 \\
37.4 \\
38 \\
36 \\
38 \\
39 \\
41 \\
37 \\
38 \\
39.4 \\
40 \\
39\end{array}$ \\
\hline
\end{tabular}

a Type.

$b$ Tail damaged.

LENOTHRIX, new genus.

Tvpe: Lenothrix canus, new species.

Characters.-Form as in the larger species of Mus; tail longer than head and body. Fur densely woolly, interspersed with long, straight hairs. Feet as in Mus, but plantar tubercles unusually large. General form of skull as in Mus, but supraorbital ridges greatly developed, somewhat as in Tylomys. Teeth essentially as in Lenomys, ${ }^{a}$ but width of upper molars only about half that of palate, and supplemental reentrant angles on inner side of these teeth less strongly developed.

LENOTHRIX CANUS, new species.

(Plate XVIII.)

Type--Adult male (skin and skull). Cat. No. 114386, U.S.N.M. Collected on Pulo Tuangku, January 27, 1902, by Dr. W. L. Abbott.

Characters.-A slender, bluish gray rat. In external appearance similar to Lenomys meyeri as figured by Meyer, ${ }^{b}$ but considerably smaller (head and body 236 instead of 290 ; hind foot 42 instead of 46), and with tail longer than head and body.

Fur.-The fur is composed of three elements: (1), a fine, dense, woolly underfur, the hairs of which at middle of back are about $12 \mathrm{~mm}$. in length; (2), slender, straight, terete hairs, the length of which in same region averages about $25 \mathrm{~mm}$., and (3), weak, flattened hairs intermediate in length between the two other kinds and most abundant on sides and underparts. The flattened hairs are very inconspicuous and might readily pass unnoticed. It is the abundant woolly underfur that determines the character of the pelage and gives the animal a very different appearance from Mus ferreocanus, which it

a As figured by Thomas, Trans. Zool. Soc. London, XIV, pl. xxxvi, fig. 1.

$b$ Abhandl. u. Berichte des k. Zool. u. Anthrop.-Ethn. Museums zu Dresden, VII, 1899, pl, vIII. 
rather closely resembles in color. In the type specimen there is an almost naked area about $4 \mathrm{~mm}$. wide and $70 \mathrm{~mm}$. in length extending along median line of belly to posterior portion of chest. It has the appearance of a normal character.

Color.- Upper parts and outer surface of limbs ecru-drab, irregularly tinged with broccoli-brown and clouded, particularly along middle of back, by the blackish long hairs. Both under fur and long hairs have a distinctly glossy texture, which causes much variation in the exact shade as the skin is viewed in different lights. Cheeks light broccoli-brown. Whiskers shining black. Underparts and inner surface of limbs cream-buff, the line of demarcation between this color and that of sides fairly well defined. Feet dirty whitish, shaded with ecru-drab, this color extending around heel. Ears blackish. Tail blackish throughout basal fourth, the rest white.

Tail.-The tail shows no peculiarities of importance. It is distinctly and uniformly annulated, about 11 rings to the centimeter at middle. The rings are not very clearly divided into scales except toward base. Beyond middle the rings become much more closely crowded, but they retain their distinctness to extreme tip. On basal fourth the hairs which spring from between the rings are too minute to cause any concealment of the annulation, but beyond this region they increase in length and slightly obscure the outlines of the rings. At tip they are about $5 \mathrm{~mm}$. long.

Ears. - The ears are of moderate size and normal form. Laid forward they extend about to eye. The surface of the ear is naked, except for a sprinkling of minute blackish hairs.

Skull. - The skull is in size and general form not unlike that of a large house rat. The brain case, however, is less deep, the audital bullæ are much smaller, the incisive foramina are shorter, the nasals flare abruptly anteriorly, and the plate of the maxillary which forms outer wall of antorbital foramen is not produced forward beyond level of upper zygomatic root. The most striking differences are found in the interorbital region. In general contour this region is much as in Mus norvegicus, but the supraorbital beads are developed into upturned blade-like ledges between which the main surface of the frontal lies at the bottom of a distinct trough. A similar condition is suggested by some skulls of very aged members of the Mus surifer group and by those of species of Tylomys.

Teeth.-Incisors as in Mus norvegicus, except that those of the upper jaw are a little less strongly curved. Molars (Plate XVIII, figs. 4 and 5) slightly larger than those of the house rat. First upper molar: The anterior ridge contains three distinct cusps, the outermost of which is nearly as large as the innermost and situated distinctly farther forward. As a result, the outer side of the tooth appears longer than the innerthe exact opposite to the condition in Mus. Between central and inner 
cusps there is a distinct reentrant angle. Another small reentrant angle lies at the posterior base of the outer cusp. 'The second ridge is practically a repetition of the first, except that the reentrant angle between middle and inner cusps is broader and not as deep, while that at posterior base of outer cusp is better developed. There is also a rudimentary reentrant angle at front of outer cusp, so that the resulting form of the cusp is an imperfect trefoil with a large median lobe, a posterior one of nearly the same size, and a minute anterior segment. In the type the process of attrition has extended far enough to unite the median ridge with the posterior along the inner edge. Third ridge with median cusp larger than in either first or second, the outer cusp rather smaller than that of first or second, and inner cusp obsolete. There is a distinct reentrant angle at posterior base of outer cusp. Second upper molar: Anterior ridge represented by a large inner cusp and a minute outer one, both joined in present state of wear to front of main cusp of second ridge. Second like that of first tooth, but with outer cusp smaller and lacking the anterior limb of the trefoil. Third ridge as in anterior tooth. Third upper molar: Anterior ridge represented by a large internal cusp, as well developed as that of middle tooth, but quite distinct from second ridge. Second ridge formed by a simple, transverse loop, narrow on the inner side, but expanding externally to a rudimentary median cusp. Third ridge consisting of a single large cusp, probably the median. It is fully as large as the median cusp of the other teeth. First lower molar: This tooth consists of three very similar bilobate cross ridges, slightly convex or concave in front, deeply concave behind. The anterior is somewhat concave anteriorly and is preceded by a small median tubercle. A similar but rather smaller tubercle lies between first and second loop on outer side, and a still smaller one between the same loops on inner side. Posterior loop like second, except that there is a small reentrant angle on outer side. It is followed by a median tubercle, rather larger than that at front of tooth. Second lower molar: Essentially a duplication of the second and third loops and posterior tubercle of first tooth, but anterior lobe with a rudimentary external tubercle and reentrant angle on outer side of second lobe deeper. Third lower molar: This tooth is reduced to an anterior loop about like that of middle tooth, and a broad, crescentic posterior loop, the slightly concave side of which is directed forward.

Measurements.-External measurements of type: Total length, 534 head and body, 236; tail, 298; hind foot, 41 (38.6).

Cranial measurements of type: Greatest length, 49.6; basal length 44.6; basilar length, 42.6; palatal length, 22; least width of palat between anterior molars, 4.8; diastema, 14.6; length of incisive fora men, 6.8; combined breadth of incisive foramina, 3.2 ; length of nasals 18; greatest combined breadth of nasals, 6.6 ; zygomatic breadth, 25 
least interorbital breadth, 5.8; breadth of brain case above roots of zygomata, 17; depth of brain case at front of basioccipital, 11.6; frontopalatal depth at posterior extremity of nasals, 11.4; least depth of rostrum immediately behind incisors, 9.6; mandible, 28.6; maxillary tooth row (alveoli), 9; width of front upper molar, 2.6; mandibular tooth row (alveoli), 8 ; width of front lower molar, 2.

Specimens examined.-One, the type.

Remarks.-Lenothix ravus is easily recognizable among Malayan rats by its woolly fur, long tail, and bluish gray color, combined with the rather large size. In general appearance it somewhat resembles Mus ferreocanus, but the quality of the fur in the two animals is quite unlike.

\section{FAMILY HYSTRICIDA.}

TRICHYS MACROTIS, new species.

Type--Adult female (skin and skull). Cat. No. 114488, U.S.N.M. Collected at Tapanuli Bay, northwestern Sumatra, February 20, 1902, by Dr. W. L. Abbott. Original number, 1555 .

Characters. - Similar to the Bornean Trichys fasciculata (Shaw) but with longer ears; skull with broader, more strongly angled hamulars.

Ears. - The ears differ from those of Trichys fasciculata in form as well as in size. The anterior border is very moderately convex and the tip is more broadly rounded off than in the Bornean animal. These two characters, in connection with the greater length, give the ear an almost spatulate appearance quite different from the contour of the ear of the related species.

Color.--The color so exactly resembles that of Trichys fasciculata as to need no description.

Skull and teeth.-The skull closely resembles that of Trichys fasciculata, except that the hamular processes of the pterygoids are of a distinctly different form. In $T$. fasciculata these processes are slender and uniformly curved throughout, the lower margin slightly thickened and the tip tapering rather abruptly to a point. In T. macrotis they are much wider, there is an abrupt angle near middle, the lower edge is not thickened, and the tip is broadened and swollen into a distinct head.

Teeth as in $T$. fasciculata.

Measurements.-External measurements of type: Total length, 653; head and body, 428; tail vertebræ, 225; hind foot, 64 (61); ear from meatus, 28. Average of four adults from the type locality: Total length, 614 (590-653); head and body, 420 (410-428); tail vertebræ, 197 (180-225); hind foot, 64 (62-66); hind foot without claws, 60.3 (58-62). For details, see table, page 470.

Cranial measurements of type: Greatest length, $82\left(84^{a}\right)$; basal

a Measurements in parentheses are those of a young adult male Trichys fasciculata from Mount Salikan, Borneo (No. 83940). 
length, 72 (72); basilar length, 68 (67); length of nasals, 27 (25.4); diastema 24 (24); zygomatic breadth, 44 (44.4); least interorbital breadth, 16 (19); mandible, 52.4 (52); maxillary toothrow (alveoli), 13.4 (14.8); mandibular toothrow (alveoli), 14.8 (15).

Specimens examined.-Five, all from the type locality.

Remarks. - Though closely related to the Bornean form, Trichys macrotis appears to be readily distinguishable by its large ears and peculiar hamulars.

An embryo with head and body about $40 \mathrm{~mm}$. in length clearly shows that scaly integument, the vestiges of which in the adult have been called attention to by Jentink. ${ }^{a}$ The scales are very distinct on the back, sides, thigh, upper arm, and proximal third of tail, much more so, in fact, than in an embryo Manis javanica of about the same size. The largest average a little more than $1 \mathrm{~mm}$. in length. Longitudinally there are about 52 rows, each of which contains 24 scales at middle of body. At the posterior border of each scale the incipient spines appear as minute rounded projections, of which the central is usually the best developed. Five of these rudiments to each scale appears to be the usual number, though seven may occasionally be counted. The middle and terminal portions of the tail lack scales, but in a favorable light traces of rings are visible along the second third. Near tip the tail rather abruptly thickens, and its surface becomes somewhat rugose.

Measurements of Trichys macrotis.

\begin{tabular}{|c|c|c|c|c|c|c|c|}
\hline Locality. & Number. & Sex. & $\begin{array}{c}\text { Total } \\
\text { length. }\end{array}$ & $\begin{array}{l}\text { Head } \\
\text { and } \\
\text { body. }\end{array}$ & $\begin{array}{c}\text { Tail } \\
\text { verte- } \\
\text { bræ. }\end{array}$ & $\begin{array}{l}\text { Hind } \\
\text { foot. }\end{array}$ & $\begin{array}{l}\text { Hind } \\
\text { foot } \\
\text { with- } \\
\text { out } \\
\text { claws. }\end{array}$ \\
\hline 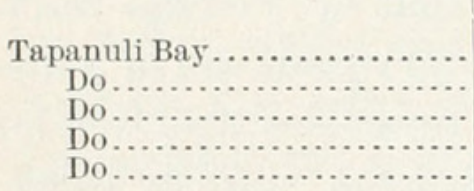 & $\begin{array}{r}114487 \\
a 114488 \\
114491 \\
114489 \\
114490\end{array}$ & 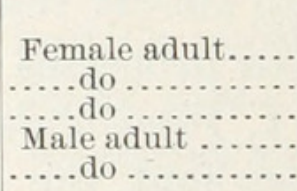 & $\begin{array}{r}m m . \\
653 \\
617 \\
590 \\
600\end{array}$ & $\begin{array}{r}m m . \\
425 \\
428 \\
422 \\
410 \\
415\end{array}$ & $\begin{array}{r}m m . \\
\ldots . . . \\
225 \\
195 \\
180 \\
185\end{array}$ & $\begin{array}{r}m m_{64} \\
64 \\
60 \\
66 \\
62\end{array}$ & $\begin{array}{r}\mathrm{mm} . \\
61 \\
\quad 60 \\
57 \\
62 \\
58\end{array}$ \\
\hline
\end{tabular}

a Type.

\section{FAMILY VIVERRIDA.}

\section{HERPESTES BRACHYURUS Gray.}

1837. Herpestes brachyurus Gray, Mag. Nat. Hist., I, November, 1837, p. 578; "Indian Islands."

A pair of adults, Tapanuli Bay, Sumatra, March 24 and 26, 1902. Measurements: Total length, male, 630, female, 650; head and body, male, 430 , female, 435 ; tail vertebræ, male, 200 , female, 215 ; hind foot, male, 83 , female, 82 ; hind foot without claws, male, 78 , female, 78 . 


\section{HEMIGALE HARDWICKII Gray.}

1830. "Viverru hardwickii GRAY, Spic. Zool., II, p. 9."

Adult female, Tapanuli Bay, Sumatra, February 12, 1902. Measurements: Total length, 830; head and body, 520; tail vertebræ, 310; hind foot, 73 (71).

\section{PARADOXURUS HERMAPHRODITUS (Pallas).}

1778. Viverra hermaphrodita PALLAs, in Schreber, Säugthiere, III, p. 426; "Barbary.",

Six specimens from Simalur Island. For measurements, see table, page 471 .

Dr. Abbott writes that the musang of Simalur Island is lighter in weight and much more slender in form than that of the Malay Peninsula. The measurements, however, show no appreciable differences, and I can detect none in the skins or skulls.

Measurements of Paradoxurus hemaphroditus.

\begin{tabular}{|c|c|c|c|c|c|c|c|}
\hline Locality. & Number. & Sex. & $\begin{array}{c}\text { Total } \\
\text { length. }\end{array}$ & $\begin{array}{l}\text { Head } \\
\text { and } \\
\text { body. }\end{array}$ & $\begin{array}{c}\text { Tail } \\
\text { verte- } \\
\text { bræ. }\end{array}$ & $\begin{array}{l}\text { Hind } \\
\text { foot. }\end{array}$ & $\begin{array}{l}\text { Hind } \\
\text { foot } \\
\text { with- } \\
\text { out } \\
\text { claws. }\end{array}$ \\
\hline 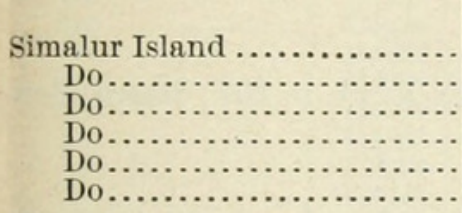 & $\begin{array}{l}114171 \\
114174 \\
114175 \\
114172 \\
114173 \\
114176\end{array}$ & 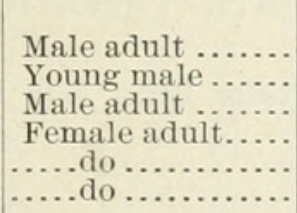 & $\begin{array}{r}m m . \\
845 \\
758 \\
875 \\
883 \\
865 \\
885\end{array}$ & $\begin{array}{r}m m . \\
465 \\
388 \\
485 \\
483 \\
470 \\
475\end{array}$ & $\begin{array}{r}m m . \\
380 \\
370 \\
390 \\
400 \\
395 \\
410\end{array}$ & $\begin{array}{r}m m . \\
68 \\
66 \\
71 \\
66 \\
71 \\
70\end{array}$ & $\begin{array}{r}m m . \\
65 \\
63 \\
70 \\
65 \\
69 \\
69\end{array}$ \\
\hline
\end{tabular}

\section{Family MUSTELID E.}

AONYX CINEREA (Illiger).

1815. Lutra cinerea Illiger, "Abhandl, Akad. Berlin, 1811, p. 99." Java.

An adult female was taken at Tapanuli Bay, Sumatra, on March 27, 1902. Measurements: Total length, 760; head and body, 470; tail vertebræ, 290 ; hind foot, 82.

\section{Family GALEOPITHECID E.}

\section{GALEOPITHECUS VOLANS (Linnæus).}

1758 [Lemur] volans Linnwus, Syst. Nat., I, 10th ed., p. 30; Asia.

Two specimens from Pulo Tuangku, Banjak Islands.

Measurements of Galeopithecus volans.

\begin{tabular}{|c|c|c|c|c|c|c|c|}
\hline Locality. & Number. & Sex. & $\begin{array}{l}\text { Total } \\
\text { length. }\end{array}$ & $\begin{array}{l}\text { Head } \\
\text { and } \\
\text { body. }\end{array}$ & $\begin{array}{l}\text { Tail } \\
\text { verte- } \\
\text { bræ. }\end{array}$ & $\begin{array}{l}\text { Hind } \\
\text { foot. }\end{array}$ & $\begin{array}{l}\text { Hind } \\
\text { foot } \\
\text { with- } \\
\text { out } \\
\text { claws. }\end{array}$ \\
\hline $\begin{array}{l}\text { Pulo Tuangku....... } \\
\text { Do................ }\end{array}$ & $\begin{array}{l}114375 \\
114376\end{array}$ & $\begin{array}{l}\text { Female, adult .... } \\
\text { Male, adult...... }\end{array}$ & $\begin{array}{r}m m . \\
620 \\
550\end{array}$ & $\begin{array}{r}m m . \\
385 \\
335\end{array}$ & $\begin{array}{r}m m . \\
235 \\
215\end{array}$ & $\begin{array}{r}m m . \\
61 \\
60\end{array}$ & $\begin{array}{l}m m . \\
55 \\
53.6\end{array}$ \\
\hline
\end{tabular}




\section{Family ERINACEID A.}

\section{GYMNURA GYMNURA (Raffles).}

1822. [Vinerra] gymnura RAfFles, Trans. Linn. Soc., London, XIII, p. 272; Bencoolen, Sumatra.

One adult male, Tapanuli Bay, Sumatra, March 29, 1902. For measurements see table, page 472.

\section{Family TUPAIID A.}

\section{TUPAIA FERRUGINEA (Raffles).}

1822. Tupaia ferruginea Raffles, Trans. Linn. Soc. London, XIII, p. 256; Singapore.

Five specimens, two from Loh Sidoh Bay and three (one skull without skin) from Tapanuli Bay. For measurements see table, page 472. Both skins and skulls closely agree with those from the southern extremity of the Malay Peninsula and show no approach toward the Tupaia phæura ${ }^{a}$ of Sinkep Island.

\section{TUPAIA TANA Raffles.}

1822. Tupaia tana RAffles, Trans. Linn. Soc. London, XXIII, p. 257; Bencoolen, Sumatra.

A pair of adults, Pulo Tuangku, Banjak Islands, January 29 and 31, 1902. For measurements see table, page 472 .

\section{TUPAIA MALACCANA Anderson.}

1879. Tupaia malaccana Anderson, Anat. and Zool. Researches, p. 134; Malacca.

A male was taken at Tapanuli Bay, Sumatra, March 22, 1902. For measurements see table, page 472 .

Measurements of Gymnura and Tupaia.

\begin{tabular}{|c|c|c|c|c|c|c|c|c|}
\hline Name. & Locality. & Number. & Sex. & $\begin{array}{c}\text { Total } \\
\text { length. }\end{array}$ & $\begin{array}{c}\text { Head } \\
\text { and } \\
\text { body. }\end{array}$ & Tail. & $\begin{array}{l}\text { Hind } \\
\text { foot. }\end{array}$ & $\begin{array}{l}\text { Hind } \\
\text { foot } \\
\text { with- } \\
\text { out } \\
\text { claws. }\end{array}$ \\
\hline 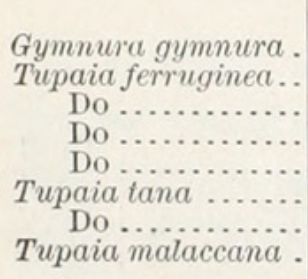 & $\begin{array}{l}\text { Tapanuli Bay .. } \\
\text { Loh Sidoh Bay . } \\
\ldots \ldots \text { do .......... } \\
\text { Tapanuli Bay .. } \\
\ldots \ldots \text { do ........... } \\
\text { Pulo Tuangku. } \\
\text { Tapano.......... }\end{array}$ & $\begin{array}{l}114551 \\
114152 \\
114153 \\
114548 \\
114549 \\
114412 \\
114413 \\
114550\end{array}$ & $\begin{array}{l}\text { Male, adult... } \\
\text { Female, adult } \\
\text { Male, adult... } \\
\text { Female, aduit } \\
\text { Male, adult... } \\
\text { Fe...do ........ } \\
\text { Male, adult... }\end{array}$ & $\begin{array}{r}m m . \\
632 \\
365 \\
a 330 \\
365 \\
390 \\
375 \\
365 \\
284\end{array}$ & $\begin{array}{r}m m . \\
377 \\
190 \\
190 \\
195 \\
200 \\
215 \\
205 \\
132\end{array}$ & $\begin{array}{r}m m . \\
255 \\
175 \\
a 140 \\
170 \\
190 \\
160 \\
160 \\
152\end{array}$ & $\begin{array}{r}m m . \\
53 \\
45 \\
47 \\
45 \\
47 \\
46 \\
45 \\
43\end{array}$ & $\begin{array}{r}m m . \\
50 \\
43 \\
44 \\
42 . \\
45 \\
43 \\
42 \\
41\end{array}$ \\
\hline
\end{tabular}

a Miller, Proc. Acad. Nat. Sci. Philadelphia, 1902, p. 157, June 11, 1902. 


\section{Family VESPERTILIONID E.}

\section{MYOTIS MURICOLA (Gray).}

1846. Vespertilio muricola Gray "Catal. Mamm., etc., Nepal and Thibet, p. 4, (ex Hodgson, nomen nudum) ;" Nepal.

Seventeen specimens (in alcohol), from Simalur Island. While it is quite possible that these do not represent true Myotis muricola, I am unable to distinguish them in the absence of material for comparison. They closely agree with specimens from Trong, Lower Siam.

Measurements of Myotis muricola.

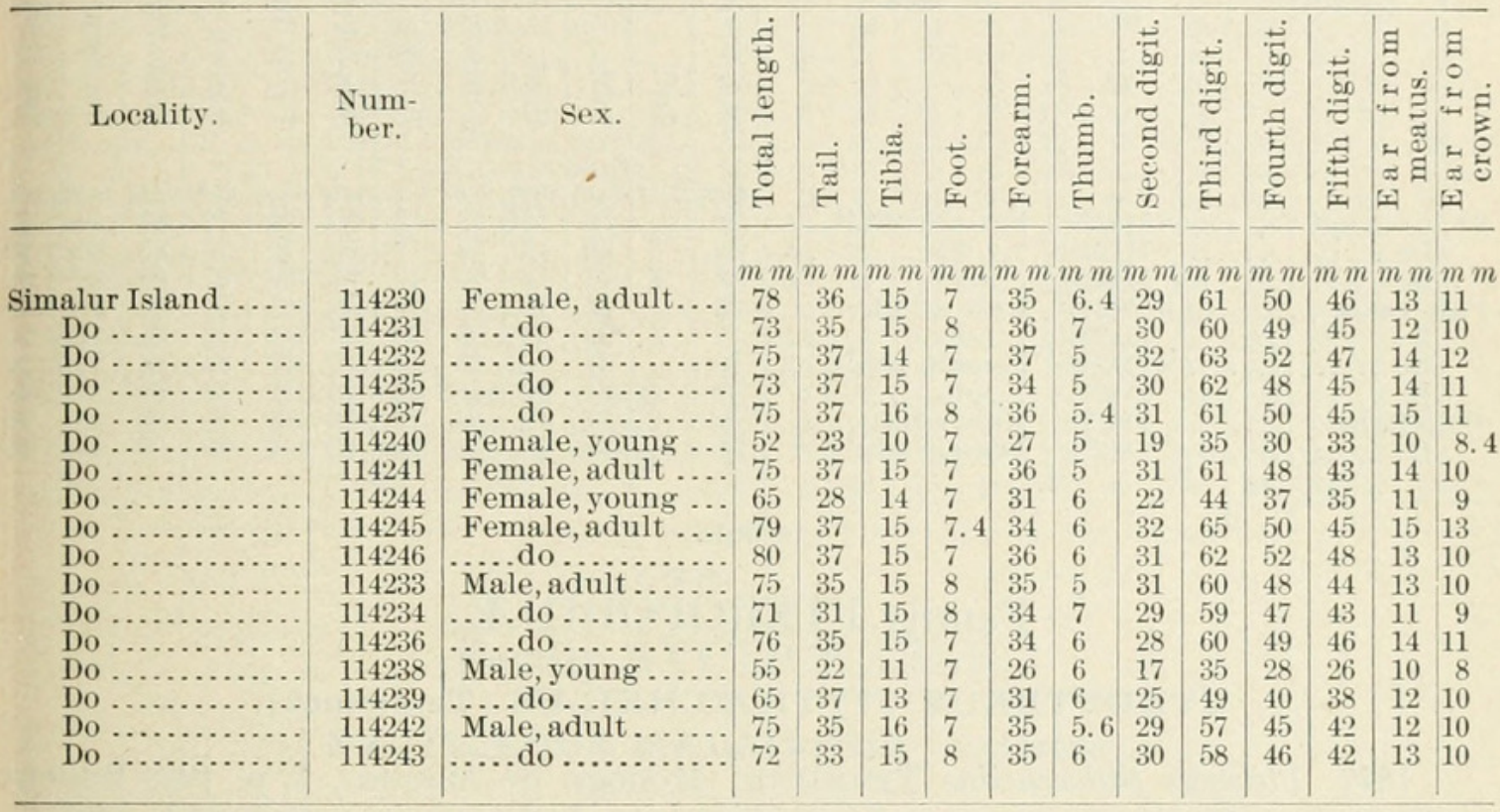

\section{Family EMBALLONURID A.}

\section{EMBALLONURA PENINSULARIS Miller.}

1898. Emballonura peninsularis Mrluer, Proc. Acad. Nat. Sci. Philadelphia, 1898, p. 323, July 25, 1898; Trong, Lower Siam.

Six specimens (in alcohol) from Pulo Babi.

Measurements of Emballonura peninsularis.

\begin{tabular}{|c|c|c|c|c|c|c|c|c|c|c|c|c|c|c|}
\hline Locality. & $\begin{array}{c}\text { Num- } \\
\text { ber. }\end{array}$ & Sex. & 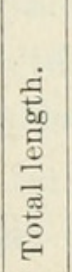 & ت્̈ & $\frac{. ّ}{\frac{\pi}{0}}$ & $\begin{array}{l}5 \\
8 \\
8\end{array}$ & 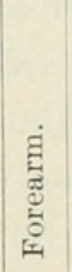 & 音 & 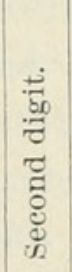 & 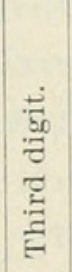 & 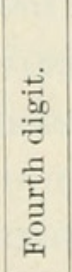 & 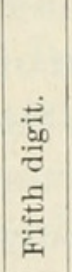 & 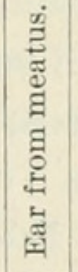 & 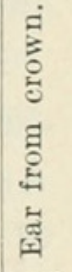 \\
\hline 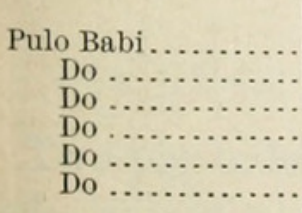 & $\begin{array}{l}114274 \\
114279 \\
114275 \\
114276 \\
114277 \\
114278\end{array}$ & 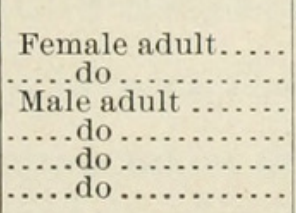 & $\begin{array}{l}m m \\
50 \\
57 \\
54 \\
53 \\
57 \\
53\end{array}$ & $\begin{array}{l}m m \\
10 \\
13 \\
13 \\
11 \\
13 \\
11\end{array}$ & $\begin{array}{l}m m \\
17 \\
16 \\
16 \\
15 \\
17 \\
17\end{array}$ & $\begin{array}{c}m m \\
8 \\
11 \\
10 \\
10 \\
9 \\
9\end{array}$ & \begin{tabular}{c}
$m m$ \\
42 \\
44 \\
44 \\
\hdashline 3 \\
43 \\
45
\end{tabular} & $\begin{array}{c}m m \\
8 \\
8 \\
8 \\
8 \\
7 \\
8\end{array}$ & $\begin{array}{l}m m \\
35 \\
37 \\
35 \\
33 \\
37 \\
35\end{array}$ & $\begin{array}{l}m m \\
62 \\
69 \\
65 \\
68 \\
66 \\
66\end{array}$ & $\begin{array}{l}m m \\
42 \\
49 \\
47 \\
45 \\
48 \\
47\end{array}$ & $\begin{array}{l}m m \\
44 \\
46 \\
44 \\
44 \\
45 \\
46\end{array}$ & $\begin{array}{l}m m \\
11 \\
13 \\
12.4 \\
12 \\
14 \\
12\end{array}$ & $\begin{array}{r}m m \\
10 \\
10 \\
11 \\
10 \\
11 \\
10\end{array}$ \\
\hline
\end{tabular}




\section{Family NYCTERID A.}

\section{MEGADERMA SPASMA (Linnæus).}

1758. [Vespertitio] spasma Linneus, Syst. Nat., I, 10th ed., p. 32; “Asia.”

Nine specimens: Pulo Siumat, off Simalur Island, 3 (2 in alcohol); Pulo Lasia, 4 (2 in alcohol); Pulo Babi, 2 (in alcohol).

Measurements of Megaderma spasma.

\begin{tabular}{|c|c|c|c|c|c|c|c|c|c|c|c|c|c|c|}
\hline Locality. & $\begin{array}{l}\text { Num- } \\
\text { ber. }\end{array}$ & Sex. & 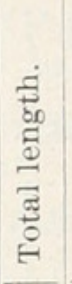 & $\underset{\tilde{E}}{\vec{Z}}$ & 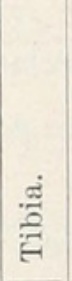 & $\begin{array}{l}\dot{0} \\
\dot{0}\end{array}$ & 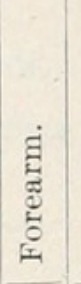 & 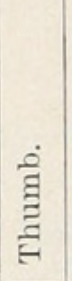 & 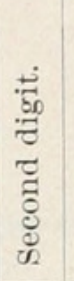 & 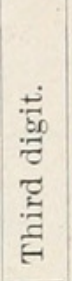 & 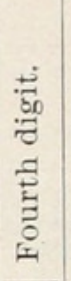 & 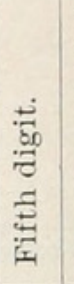 & 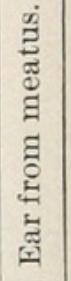 & 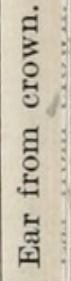 \\
\hline 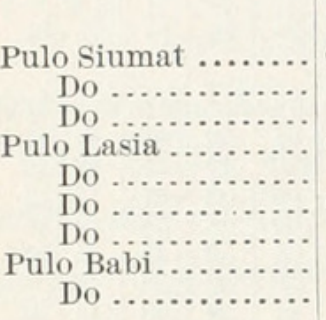 & $\begin{array}{r}a 114227 \\
114228 \\
114229 \\
a 114249 \\
114252 \\
a 114250 \\
114251 \\
114272 \\
114273\end{array}$ & 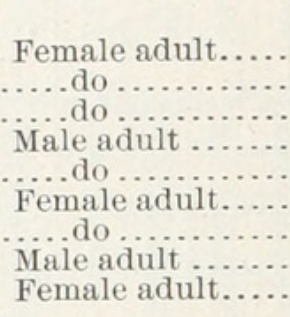 & $\begin{array}{c}m m \\
75 \\
69 \\
68 \\
80 \\
77 \\
85 \\
70 \\
78 \\
79\end{array}$ & $\begin{array}{c}m m \\
\cdots \\
5 \\
3 \\
\ldots \ldots \\
2 \\
\ldots \\
4 \\
2 \\
\ldots\end{array}$ & $\begin{array}{c}m m \\
32 \\
33 \\
30 \\
32 \\
29 \\
33 \\
34 \\
31 \\
33\end{array}$ & $\begin{array}{l}m m \\
18 \\
15 \\
17 \\
19 \\
20 \\
19 \\
19 \\
19 \\
19\end{array}$ & \begin{tabular}{|c|}
$\mathrm{mm}$ \\
58 \\
59 \\
60 \\
59 \\
58 \\
60 \\
61 \\
59 \\
$\ldots$
\end{tabular} & $\begin{array}{c}\mathrm{mm} \\
19 \\
19 \\
17 \\
19 \\
20 \\
19 \\
19 \\
18 \\
20\end{array}$ & $\begin{array}{c}m m \\
50 \\
53 \\
51 \\
56 \\
53 \\
55 \\
55 \\
53 \\
53\end{array}$ & $\begin{array}{l}\mathrm{mm} \\
105 \\
110 \\
109 \\
101 \\
108 \\
107 \\
110 \\
108 \\
112\end{array}$ & $\begin{array}{c}m m \\
78 \\
79 \\
81 \\
81 \\
82 \\
84 \\
84 \\
80 \\
85\end{array}$ & $\begin{array}{c}\mathrm{mm} \\
83 \\
82 \\
85 \\
81 \\
85 \\
83 \\
88 \\
83 \\
88\end{array}$ & $\begin{array}{c}\mathrm{mm} \\
39 \\
36 \\
36 \\
37 \\
37 \\
36 \\
38 \\
36 \\
37\end{array}$ & $\begin{array}{r}m m \\
31 \\
30 \\
30 \\
30 \\
30 \\
29 \\
31 \\
2 £ \\
30\end{array}$ \\
\hline
\end{tabular}

\section{Family PTEROPODID AE.}

\section{CYNOPTERUS TITTHÆCHEILUS (Temminck).}

1827. Pteropus titthrcheilus Temminck, Monogr. de Mamm., I, p. 198; Buitenzorg, Java.

1902. Cynopterus titthrcheilus Stone and Rehn, Proc. Acad. Nat. Sci. Philadel phia, 1902, p. 136, June 4, 1902.

Twenty-four, from the following localities: Pulo Babi, 3 (2 in alco hol); Tapanuli Bay, Sumatra, 21 (19 in alcohol). They closely agref with specimens of true Cynopterus titthxcheilus from Java, and are readily distinguishable from the $C$. montanoi of the southern extremity of the Malay Peninsula by their larger general size, and particularly by their large skulls and heavy teeth. As in $C$. montanoi the ear show no indication of a whitish border.

The original description of this species was based on material fron Java, Sumatra, and Siam. It therefore included Cynopterusmontanoi As Temminck expressly states that most of his specimens were take at Buitenzorg, Java, it is safe to regard this as the type locality. 
Measurements of Cynopterus titthxcheilus.

\begin{tabular}{|c|c|c|c|c|c|c|c|c|c|c|c|c|c|c|}
\hline Loeality. & $\begin{array}{l}\text { Num- } \\
\text { ber. }\end{array}$ & Sex. & 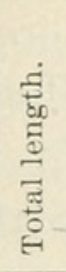 & 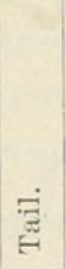 & $\frac{\frac{\pi}{3}}{\frac{\pi}{E}}$ & $\begin{array}{l}\text { ठ } \\
8 \\
\text { c }\end{array}$ & 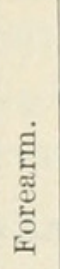 & 音 & 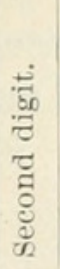 & 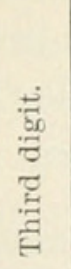 & 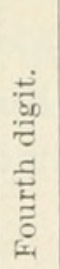 & 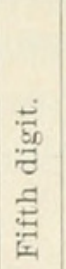 & 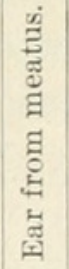 & 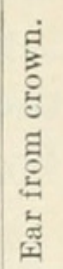 \\
\hline & & & $\mathrm{mm}$ & $m m$ & $m m$ & $m m$ & $m m$ & $m m$ & $\mathrm{~mm}$ & $m m$ & $m m$ & $m m$ & $m m$ & \\
\hline $\begin{array}{r}\text { Pulo Babi... } \\
\text { Do } \ldots . . .\end{array}$ & a 114269 & Female adult... & 103 & 8 & 25 & 15 & 65 & 27 & 46 & 108 & 85 & 85 & 13 & \\
\hline Do $\ldots \ldots \ldots$ & $\begin{array}{l}114271 \\
114270\end{array}$ & Male adult . & $\begin{array}{l}93 \\
95\end{array}$ & $\begin{array}{l}8 \\
6\end{array}$ & $\begin{array}{l}27 \\
25\end{array}$ & $\begin{array}{l}15 \\
15\end{array}$ & $\begin{array}{l}66 \\
67 \\
67\end{array}$ & $\begin{array}{l}26 \\
95\end{array}$ & 44 & 112 & 88 & $\begin{array}{l}86 \\
86\end{array}$ & 17 & 16 \\
\hline Tapanuli Bay. & a 114466 & ..do... & 113 & 10 & 27 & 18 & 68 & 28 & $\begin{array}{l}42 \\
46\end{array}$ & 110 & 86 & 89 & $\begin{array}{l}18 \\
15\end{array}$ & \\
\hline Do ......... & 114486 & Male, young... & 87 & 9 & 21 & 16 & 60 & 28 & 43 & 93 & 74 & 74 & 17 & 15 \\
\hline Do & a 114467 & Female adult... & 110 & 8 & 28 & 17 & 66 & 29 & 46 & 107 & 88 & 86 & 16 & \\
\hline Do & 114468 & Female, young . & 86 & 10 & 24 & 15 & 62 & 25 & 41 & 97 & 79 & 78 & 17 & \\
\hline Do & 114469 & Female adult... & 96 & 10 & 24 & 14 & 61 & 28 & 43 & 109 & 83 & 83 & 18 & 16 \\
\hline Do & 114470 & $\ldots$. do $\ldots \ldots$. & 90 & 10 & 23 & 15 & 65 & 26 & 44 & 106 & 81 & 80 & 17 & 15 \\
\hline Do & 114471 & ...do $\ldots$......... & 94 & 9 & 24 & 17 & 67 & 26 & 44 & 110 & 85 & 85 & 18 & 16 \\
\hline Do & 114472 & do & 93 & 9 & 24 & 15 & 65 & 27 & 44 & 109 & 83 & 81 & 19 & 17 \\
\hline Do & 114473 & Female, you & 85 & 9 & 23 & 17 & 63 & 22 & 43 & 103 & 78 & 77 & 18 & 15 \\
\hline Do & 114474 & Female adult... & 93 & 8 & 25 & 14 & 66 & 26 & 43 & 110 & 85 & 83 & 18 & 15 \\
\hline Do & 114475 & $\ldots \ldots$ do $\ldots \ldots \ldots$ & 89 & 9 & 24 & 16 & 65 & 26 & 45 & 110 & 89 & 90 & 20 & 17 \\
\hline Do & 114476 & $\ldots$ do $\ldots$......... & 90 & 10 & 26 & 15 & 68 & 26 & 43 & 110 & 83 & 82 & 18 & 17 \\
\hline Do & 114477 & do. & 92 & 10 & 25 & 16 & 66 & 27 & 42 & 107 & 86 & 80 & 18 & 15 \\
\hline & 114478 & do... & 93 & 10 & 23 & 15 & 64 & 25 & 42 & 103 & 79 & 78 & 16 & 15 \\
\hline Do . & 114479 & do .. & 90 & 9 & 22 & 18 & 66 & 28 & 44 & 109 & 83 & 80 & 19 & 15 \\
\hline & 114480 & $\cdots$ & 9 & 10 & 26 & 16 & 67 & 29 & 46 & 107 & 85 & 83 & 17 & \\
\hline Do & 114481 & $\ldots . . d c$ & 95 & 10 & 23 & 17 & 66 & 29 & 48 & 111 & 85 & 85 & 18 & 15 \\
\hline Do . & 114482 & Female, young & 88 & 7 & 23 & 15 & 63 & 25 & 41 & 100 & 84 & 79 & 18 & 14 \\
\hline Do . & 114483 & Female adult... & 100 & 9 & 25 & 14 & 64 & 27 & 41 & 107 & 82 & 81 & 17. 6 & 15 \\
\hline Do ...... & 114484 & Female, young . & 85 & 8 & 26 & 15 & 60 & 27 & 40 & 104 & 78 & 77 & 17 & 14 \\
\hline Do $\ldots . . .$. & 114485 & $\ldots .$. do $\ldots . . . . . .$. & 88 & 8 & 24 & 16 & 64 & 26 & 45 & 105 & 83 & 83 & 19 & 16 \\
\hline
\end{tabular}

a Skin.

\section{Family NYCTICEBID A.}

\section{NYCTICEBUS MALAIANUS (Anderson).}

1881. [Nycticebus tardigradus] var. malaiana Anderson, Catal. Mamm. Indian Mus., I, p. 95; Malacca.

1902. Nycticebus coucang malaianus Stone and Rehn, Proc. Acad. Nat. Sci. Philadelphia, 1902, p. 139, June 4, 1902.

An adult male was taken at Tapanuli Bay on March 20, 1902. Measurements: Total length, 328 ; head and body, 312; tail vertebræ, 16 ; hind foot, 65 .

This specimen has been examined by Mr. Stone and Mr. Rehn, who write me that they consider it "undoubtedly malaianus." Although Anderson mentions no type specimen in his original description of the form, the stuffed adult male and its skull which heads his list of material (p. 96) may be regarded as the type. This was collected at Malacca.

\section{Family CERCOPITHECID Æ.}

\section{MACACUS NEMESTRINUS (Linnæus).}

1766. [Simia] nemestrina Linneus, Syst. Nat., I, 12th ed., p. 35; Sumatra.

Two pig-tailed macaques taken at Tapanuli Bay, Sumatra, were the only individuals of the species observed. For measurements, see table, page 477 . 
MACACUS “CYNOMOLGUS” Auct.

Macacus cynomolgus Auct., not Simia cynomolgus Linnsus.

Seven specimens of the common crab-eating macaques were obtained. three on Pulo Tuaugku, two on Pulo Mansalar, and two at Tapanul Bay, Sumatra. For measurements, see table, page 477.

MACACUS FUSCUS, new species.

Type--Old male (skin and skull). Cat. no. 114164, U.S.N.M Collected on Simalur Island, northwestern Sumatra, November 20 1901, by Dr. W. L. Abbott. Original number, 1348.

Characters. - Similar to Macacus umbrosus ${ }^{a}$ of the Nicobar Islands but smaller and with relatively shorter tail.

Color-Type: Upperparts and outer surface of limbs blackisl brown with a paint tinge of drab, each hair drab at base and with : wood-brown annulation 2 to $4 \mathrm{~mm}$. in width near tip. As the fur i of a soft, silky quality, the exact effect of the two colors varies con siderably with reflection of light and with disarrangement of hairs, bu the wood-brown is everywhere very distinct though not in excess o the dark underlying brown. Underparts and inner surface of limbs light bluish gray (very nearly Ridgway's No. 8). This color suffuse cheeks and region surrounding ears. Tail like back above, but wit the light annulations very indistinct, like belly below and at tip.

Skull and teeth.- The skull and teeth resemble those of Macacu umbrosus except for their much smaller size.

Measurements. - External measurements of type: Total length, 920 head and body, 470; tail vertebræ, 450; hind foot, 125 Average c five males from the type locality: Total length, 939 (905-985); hea and body, 478 (460-495); tail vertebræ, 467 (435-490); hind foot, 12 (118-130). For details see table, page 477.

Cranial measurements of type: Greatest length (exclusive of inc sors), $122(134) ;^{b}$ basal length, 93 (102); basilar length, 87 (96); lea: palatal length, 49 (57); palatal breadth (between front molars), 21 (25 zygomatic breadth, $83(90)$; mastoid breadth, 64 (71); greatest breadt of brain case above roots of zygomata, $60(61)$; least breadth of bra case immediately behind orbits, 38.6 (39); orbital breadth, 61 (67 least distance from orbit to alveolus of inner incisor, 44 (49); greate depth of brain case (exclusive of sagittal crest), 45 (50); mandibl 82 (97); greatest depth of ramus, 19 (19.6); maxillary tooth ro (exclusive of incisors), 40 (44.6); mandibular tooth row (exclusive ? incisors), 45 (50); crown of middle upper molar, 7.4 by 7 ( 8.8 by 8 crown of middle lower molar, 8 by 6 ( 8.2 by 7.4$)$.

Specimens examined.-Ten, eight from Simalur Island and two fro Pulo Lasia.

$a$ Miller, Proc. U. S. Nat. Mus., XXIV, May 28, 1902, p. 789.

$b$ Measuremente in parentheses are those of the type of Macacus umbrosus, a you adult male, with unworn teeth. 
Remarks.-In color and size the specimens from Simalur Island are very constant, presenting no variation worthy of note. In the two from Pulo Lasia the tail is considerably longer, making the proportions essentially the same as in Macacus umbrosus. They are readily separable from the Nicobar species, however, by their much smaller skulls.

Measurements of Macacus.

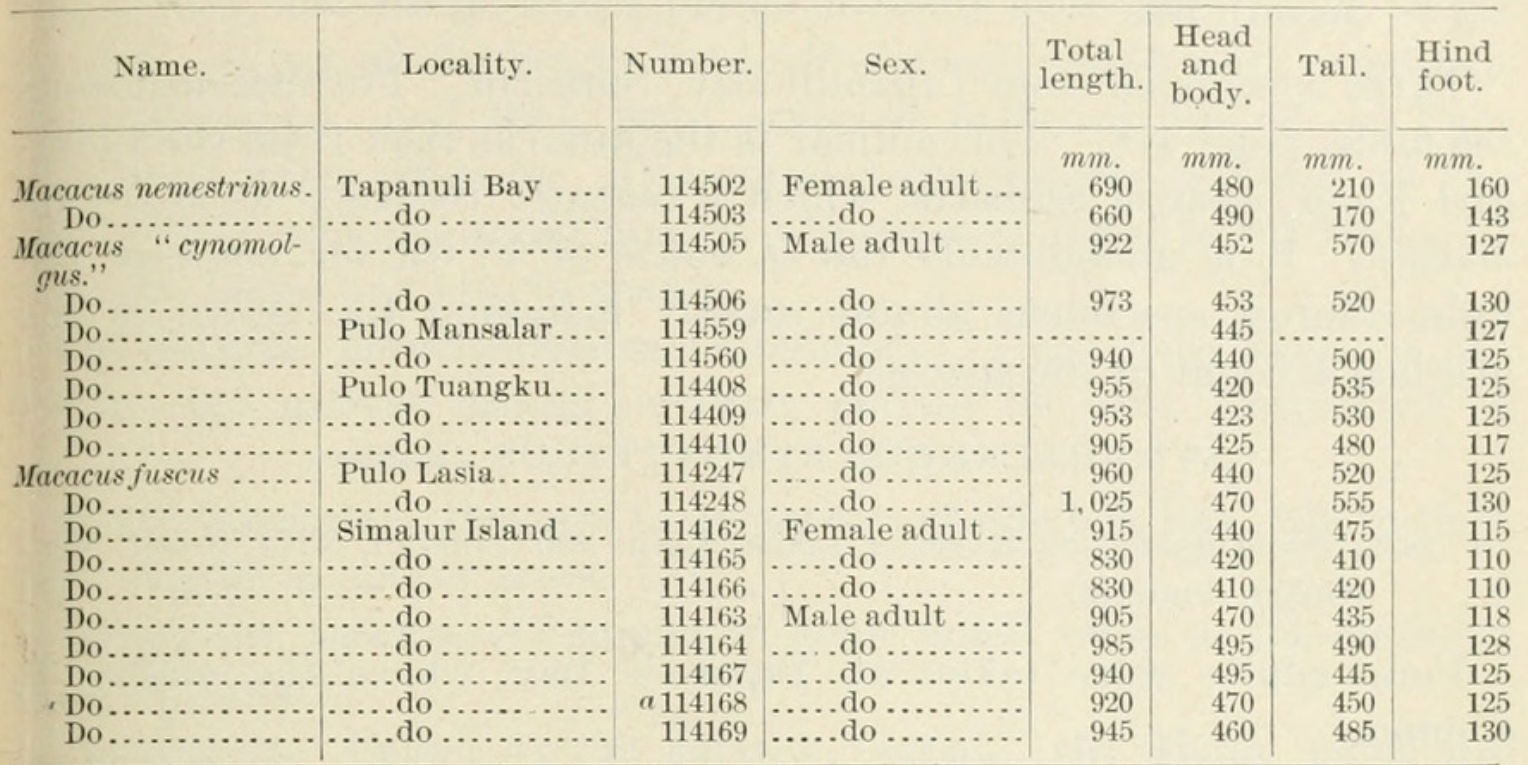

a Type.

\section{PRESBYTES $a$ SUMATRANUS (Müller and Schlegel).}

1839-1844. Semnopithecus sumatranus MüLLer and ŚCHLEgel, Verhandel. over de natuurlijke Geschiedenis der Nederl. overzeesche bezittingen, p. 73; Sumatra.

Four specimens taken at Tapanuli Bay, Sumatra, are essentially identical with those previously collected by Dr. Abbott on the Indragiri River, eastern Sumatra. ${ }^{b}$ For measurements see table, page 477.

PRESBYTES CRISTATUS (Raffles).

1822. Simia cristata Raffles, Trans. Linn. Soc. London, XIII, p. 244; Bencoolen, Sumatra.

One skin from Loh Sidoh Bay and five from Tapanuli Bay, Sumatra. For measurements see table:

Measurements of Presbytes.

\begin{tabular}{|c|c|c|c|c|c|c|c|}
\hline Name. & Locality. & Number. & Sex. & $\begin{array}{c}\text { Total } \\
\text { length. }\end{array}$ & $\begin{array}{l}\text { Head } \\
\text { and } \\
\text { body. }\end{array}$ & Tail. & $\begin{array}{l}\text { Hind } \\
\text { foot. }\end{array}$ \\
\hline 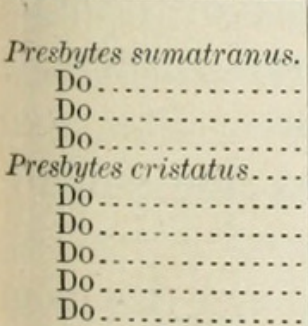 & 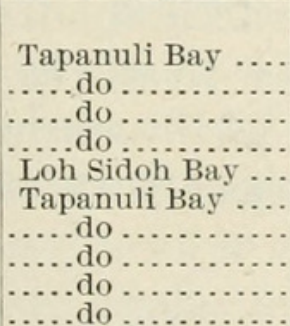 & $\begin{array}{l}114507 \\
114508 \\
114509 \\
114510 \\
114160 \\
114512 \\
114513 \\
114515 \\
114514 \\
114516\end{array}$ & 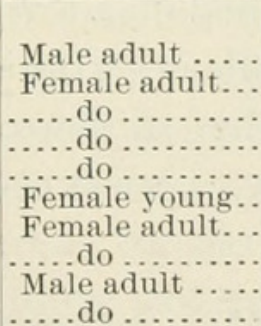 & $\begin{array}{l}m m . \\
1,270 \\
1,230 \\
1,260 \\
1,215 \\
1,200 \\
950 \\
1,190 \\
1,130 \\
1,290 \\
1,295\end{array}$ & $\begin{array}{r}m m . \\
510 \\
500 \\
515 \\
455 \\
500 \\
400 \\
530 \\
465 \\
540 \\
540\end{array}$ & $\begin{array}{r}m m . \\
760 \\
730 \\
745 \\
760 \\
700 \\
550 \\
660 \\
665 \\
750 \\
755\end{array}$ & $\begin{array}{r}m . \\
160 \\
170 \\
165 \\
165 \\
145 \\
132 \\
150 \\
145 \\
163 \\
163\end{array}$ \\
\hline
\end{tabular}

a Presbytes Eschscholtz, Kotzebue's Entdeckung's Reise, III, 1821, p. 196, type P. mitratus Eschscholtz, antedates Semnopithecus F. Cuvier, Des Dents des Mammifères, 1825 , pp. 14, 247, the first publication of the more familiar name in Latin form. ${ }^{b}$ See Proc. Acad. Nat. Sci. Philadelphia, 1902, p. 159, June 11, 1902. 


\section{Family SIMIID A. \\ HYLOBATES AGILIS F. Cuvier.}

1821. Hylobates agilis F. Cuvier, Hist. Nat. des Mammifères, III, Pts. 32 and 33. September, 1821; Sumatra.

1902. Hylobates hoolock Mrluer, Proc. Acad. Nat. Sci. Philadelphia, 1902, p. 159 June 11, 1902.

Three specimens from Tapanuli Bay, Sumatra. For measurements see table, page 478. This animal is the same as that from the Indra giri River, eastern Sumatra, which I recently recorded as Hylobates hoolock. It is undoubtedly the $\Pi$. agilis of F. Cuvier, some of the light-colored specimens almost exactly matching the figure in the original account of the species.

\section{SYMPHALANGUS SYNDACTYLUS (Raffles).}

1822. Simia syndactyla RAffles, Trans. Linn. Soc. London, XIII, p. 241; Ben coolen, Sumatra.

Four adults were taken at Tapanuli Bay, where the animal i: common.

Measurements of Hylobates and Symphalangus from Tapanuli Bay.

\begin{tabular}{|c|c|c|c|c|}
\hline Name. & Number. & Sex. & $\begin{array}{c}\text { Total } \\
\text { length. }\end{array}$ & $\begin{array}{l}\text { Hind } \\
\text { foot. }\end{array}$ \\
\hline 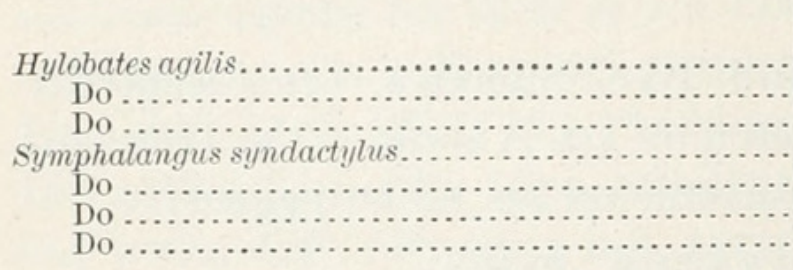 & $\begin{array}{l}114499 \\
114500 \\
114501 \\
114494 \\
114497 \\
114495 \\
114496\end{array}$ & 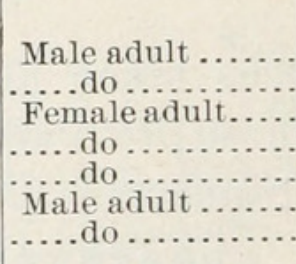 & $\begin{array}{r}\mathrm{mm}_{\mathrm{m}} . \\
470 \\
445 \\
415 \\
470 \\
500 \\
510 \\
525\end{array}$ & $\begin{array}{r}m m . \\
12 \\
12 \\
12 \\
14 \\
15 \\
1 \% \\
1 \%\end{array}$ \\
\hline
\end{tabular}

NOTES ON THE FAUNA OF THE LOCALITIES VISITED.

Lists of the mammals observed at the different collecting station follow, together with the collector's field notes.

Loh Sidoh Bay, Sumatra (November 5 to 8, 1901).

Sciurus albescens.-Common in jungles and cocoanut plantations. Mus lingensis.-Trapped on a low, jungle-covered hill east of the bay Tupaia ferruginea Raffles.-Found in dense jungle by the seashore. Presbytes maurus.- Shot in dense jungle by the seashore.

"Saw tracks of tiger, Cervus equinus, pig, kijang, etc., but did no secure any specimens."

Simalur Island (November 16, 1901, to January 2, 1902).

Sus vittatus.-Pigs are very common. One meets with their track and "diggings" everywhere; but except where sago is being mad 
they are hard to catch sight of. An adult female (No. 114177) was killed in the forest while feeding on the trunk of a sago palm. Others were killed in clearings and among the mangroves on the shore.

\section{Mus simalurensis.}

Mus surdus.- No rats were caught in the forest, though many traps were set there. Afterwards the traps were moved to stumps, dead tree trunks, and stony, weedy places in paddy fields with much better results. A few of the larger kind (Mus simalurensis) were caught in these situations, and they were common in heavy jungle on Pulo Siumat, 5 miles offshore. The smaller species was common in the paddy fields, and also about houses. Some were found in the stomachs of snake eagles and also in snakes.

Paradoxurus hermaphroditus.-Common. Only once seen in the jungle, but natives eaught several; said to be very destructive to poultry.

Myotis muricola.-Brought in by natives at Sibaboh Bay, where they were caught in hollow trees.

Megaderma spasma. - Obtained in some small caves at the seashore on Pulo Siumat.

Pteropus sp. - Called by the natives "tupai," the Malay name for squirrel. A "camp" existed on Pulo Asu and two others were said to be on Pulo Siumat. Although frequently seen flying about in the evening, no specimens were secured.

Macacus fuscus.-Common. Has the usual habits of Macacus. The only monkey on the island.

\section{Pulo Lasia (January 4 to 7,1902 ).}

Mus simalurensis.-Common in the jungle.

Megaderma spasma. - A bunch of four were shot while hanging under a projecting rock in the jungle.

Macacus fuscus.-Common. Is not found on the neighboring Pulo Babi.

\section{Pulo Babi (January 7 to 14, 1902).}

Sus vittatus. - Although no pigs occur on Pulo Lasia they are abundant on Pulo Babi, but are not easily seen in the dense jungle. Only three were shot. Their "sarongs" or nests were very common in the jungle. These are generally made of the leaves of a small palm and resemble little haycocks. The pig of Babi appears to be different from that of Simalur. It is considerably larger.

Mus simalurensis.-A large gray rat was not uncommon, but all the specimens trapped were so cut to pieces by crabs that no skins could be saved. Several skulls, however, were preserved.

Emballonura peninsularis.-No notes.

Cynopterus titthæchæilus.-Common. Found hanging by day from the midribs of the leaves of an areca palm. 
Pulo Bangkaru, Banjak Islands (January 16 to 21, 1902).

No pigs or monkeys were seen, and the natives say that none occur. A number of Pteropus were seen, and at least two kinds of smaller bats, but none were obtained. My Malay sailing master said that he saw a red "tupai" on the ground. It was probably the form of Tupaia tana afterwards taken on Pulo Tuanku.

Tragulus brevipes.--Several seen; only one taken.

Sciurus pretiosus.-Common.

Sciurus bancarus.-Very common.

Mus firmus.

Mus fremens.

Mus lingensis. - Rats were very plentiful, but land and hermit crabs abounded to such an extent that trapping was difficult and many of the specimens eaught were ruined.

Pulo Tuangku, Banjak Islands (January 22 to February 5, 1902).

Tragulus russeus.-Very common. Am not certain whether ther are one or two forms. Three males weighed over 5 pounds each, bu none of the females were so large. Now in Tragulus the female $\mathrm{i}$ considerably larger than the male; but no correspondingly larg, females were obtained among the thirty or more that I examined Most of the females were pregnant.

Sus vittatus.-A rather small form. Common, but only one femal and an immature male obtained.

Sciurus ubericolor.-Common.

Ratufa palliata.-

Ratufa femoralis.-Both very common and very noisy. Often see together in the same tree. When alive the brown one (femorali appears smaller than the other.

Rhinosciurus laticaudatus. - A female was caught in a rat trap a Ujong Tumbaga.

Mus firmus.-

Mus fremens.

Mus asper.

Mus lingensis.--All four species of Mus were common.

Lenothrix canus. - Only one taken.

Galeopithecus volans.-Common.

Macacus "cynomolgus." - Common. A small form similar to that c Sumatra.

Pulo Mansalar, at entrance to Tapanuli Bay (March 2 to 1 1902).

A monkey, apparently identical with the Presbytes maurus of tl mainland, was observed, but no specimen could be secured. It w shy and not very common. The tracks of pigs were abundant, $b$ 
none of the animals themselves were seen. Natives reported Galeopithecus common, and also said that no musangs occur.

Tragulus amœnus.- Two were brought in by natives.

Tragulus jugularis.-Common. About thirty were brought in by natives. Three Nias men with two dogs went to the northwest end of the island, and returned in two days with fourteen napu, so the animals must be very plentiful.

Sciurus saturatus.-Common.

Sciurus mansalaris.-Very common. Crepuscilar, but a few may be seen at all hours.

Ratufa nigrescens. - Common, but neither as plentiful nor as noisy as the species of Pulo Tuangku.

\section{Mus domitor.-}

Mus fremens.-

Mus catellifer.-All three species of rats were common.

Tapanuli Bay, Northwestern Sumatra (February 12 to 28 at Lobo Pandan Bay, and March 16 to 29 at Jaga Jaga).

No elephants are in the immediate vicinity, but they are said to be common only a few miles away. A rhinoceros is said to have come close to the village while I was at Lobo Pandan.

Rusa.-A female or young male seen.

Cervulus.-Heard at Lobo Pandan. One seen.

Tragulus kanchil.-Very common.

Tragulus napu.- Several snared and brought in, but all were immature except one fine male. If this is typical napu, as it probably is, it is a different animal from any that I have heretofore obtained.

Sus.-None seen, but their tracks were everywhere plentiful.

Sciurus vittatus.-Common.

Sciurus tenuis.-Common.

Sciurus erebus.-Generally common, but less so than the last. A good many met with in the mangroves, and particularly in the cocoanuts at Jaga Jaga village.

Ratufa palliata.--Not very common. Heard several times at Lobo Pandan. A pair often seen and fired at unsuccessfully on Gunong Kebong, where a half-grown female was finally shot.

\section{Mus firmus.-}

\section{Mus fremens.}

Mus lingensis.-All three rats were common.

Mus asper.-Only one taken.

Trichys macrotis. - Several caught by Malays on Bukit Sawa.

Herpestes brachyurus. - A pair were caught by Malays in a jerat (snare) on Bukit Sawa.

Paradoxurus.-No skins. A half-grown female brought to me alive is now (April 6) well and growing fast. While it does not look

Proc. N. M. vol. xxvi-02-33 
like the $P$. hermaphoditus of the peninsula, it closely resembles the form found on Simalur; so the latter may have been introduced. ${ }^{a}$ The Malays often keep musangs as pets.

Hemigale hardwickii.-One snared by Malays on Bukit Sawa.

Aonyx cinerea.-A female snared on Bukit Sawa. It is apparently adult, though weighing only $5 \frac{3}{4}$ pounds.

Gymnura gymnura.-One caught alive by a Malay on Bukit Sawa.

Tupaia ferruginea.-Apparently not common. Three specimens obtained at Lobo Pandan.

Pteropus sp.-Often seen flying over Jaga Jaga. Two were shot, but fell into the water and were lost. Pteropus usually sinks in water unless very fat.

Cynopterus titthæcheilus.-A bunch of twenty females were found hanging on a cocoanut leaf at Jaga Jaga. All were killed at one shot. A male found hanging alone on another tree about 20 feet away was also shot.

Nycticebus malaianus.-One brought in alive. Malay name, "konkong." The animal is much used in medicine and magic.

Presbytes sumatranus. - Not as common as $P$. maurus, and keeps more strictly to the hills and heavy forests. Local name, "boóro."

Presbytes maurus.-Common, especially among the mangroves. Local name, "chinko."

Macacus nemestrinus.-Malay name, "broh," but locally called "běróh." Met with a number of times, but only two, both females, shot. These short-tailed Macacus are always shy and hard to get. Did not observe them in captivity in Sumatra, although I have seen many in other places trained to climb for cocoanuts. A well-trained broh is said to sell for $\$ 20$ to $\$ 25$ (Straits dollars) in the Straits Settlements.

Macacus "cynomolgus." - Malay name Krah, from its call. About Tapanuli the local name is Káro. Very common. Apparently a rather small form. Some few males seem to grow to a large size. I shot one very large male, but he tumbled into the river and sank immediately. I do not think that more than one male in a hundred ever reaches this large size-probably 15 or 16 pounds. It is the same with $M$. cynomolgus everywhere.

Hylobates agilis.-Common; some are pale brown and some black. A brown female (No. 114501), killed on February 22, had a black husband and a black baby. Gibbons are monogamists.

Symphalangus syndactylus.-Common. Their extraordinary cries heard everywhere about Tapanuli Bay, also at Tapat Tuan, 140 miles farther up the coast. A new born young, killed by the same sho1

${ }^{a}$ In a letter dated September 26, 1902, Dr. Abbott writes that this musang, nov nearly adult, has grown to resemble in all respects the common $P$. hermaphroditus 0 the Malay Peninsula. 
which killed its mother, was naked except on its scalp. A few days after another female was shot. This had a baby about a month old, which is now (April 6) well covered with hair and has cut all its milk incisors. It thrives on condensed milk and bananas and is too affectionate to be an altogether agreeable pet. A later note says that this siamang died of diarrhea on April 14.

Simia.-The orang utan exists, but not abundantly, about Tapanuli Bay. Two miles up the Jaga Jaga River some nibong palms were seen that had been broken off by orangs, and also an old sarong (shelter), but the traces were old. There were said to be more a few miles farther inland, particularly up the Berdiri River. The natives say they always go about in pairs. This is probably true, as all the siamang I met with were in pairs, and all gibbons, as far as I know, are monogamous. Often one meets with two or more pairs on a favorite fruit tree, and, of course, they have young ones with them; but they never go in gangs like Macacus and Pusbytes, and it is usual for a pair to be alone or with one baby.

\section{EXPLANATION OF PLATES.}

Plate XVIII.

Lenothrix canus, Type.

Figs. 1-3, skull (natural size); fig. 4, crowns of lower molars (about $\times 4$ ); fig. 5 , crowns of upper molars $($ about $\times 4)$.

\section{Plate XiX.}

Ratufa lænata R. palliata.

Figs. 1-9, posterior termination of nasals and premaxillaries in 9 skulls of Ratufa lænata; figs. 10-12, the same in 3 skulls of $R$. palliata; figs. 13-21, anterior termination of maxillaries in 9 skulls of $R$. lænata; figs. 22-24, the same in 3 skulls of $R$. palliata (all about $\times 1.75)$.

Figs. 1 and 13, male, No. 114352.

2 and 14, female, No. 114349.

3 and 15 , male, No. 114354 .

4 and 16 , female, No. 114355 .

5 and 17 , male, No. 114346.

6 and 18 , male, No. 114356.
Figs. 7 and 19, male, No. 114357.

8 and 20 , male, No. 114350. Type.

9 and 21, female, No. 114347.

10 and $22,-$, No. 114003.

11 and $23,-$, No. 114004.

12 and 24 , male, No. 113162. Type.

Nos. 1-9, 13-21, from Pulo Tuanku; Nos. 10-11, 22-23, from Sumatra, exact locaity not known; Nos. 12 and 24, from the Indragiri River, eastern Sumatra. 

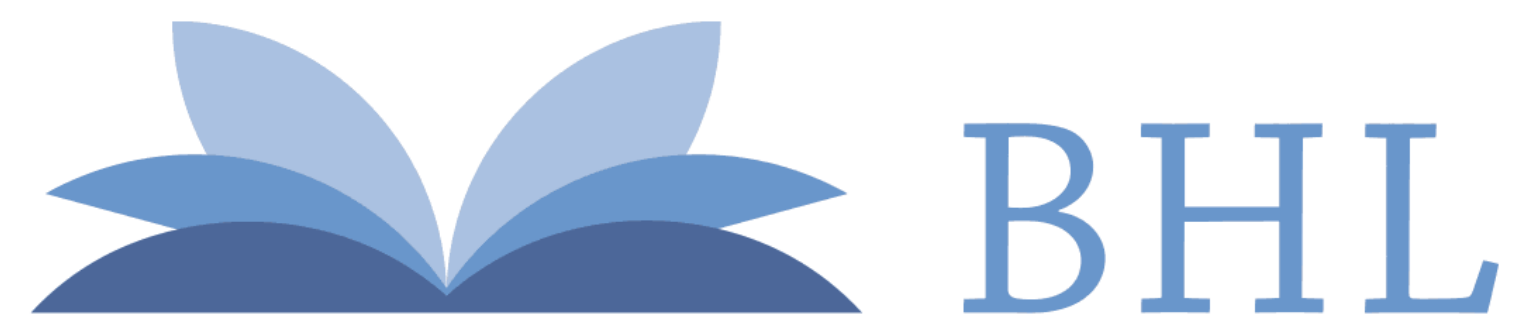

\section{Biodiversity Heritage Library}

Miller, Gerrit S. 1903. "Mammals collected by Dr. W. L. Abbott on the coast and islands of northwest Sumatra." Proceedings of the United States National Museum 26(1317), 437-483. https://doi.org/10.5479/si.00963801.26-1317.437.

View This Item Online: https://www.biodiversitylibrary.org/item/32571

DOI: https://doi.org/10.5479/si.00963801.26-1317.437

Permalink: https://www.biodiversitylibrary.org/partpdf/9434

\section{Holding Institution}

Smithsonian Libraries

\section{Sponsored by}

Smithsonian

\section{Copyright \& Reuse}

Copyright Status: NOT_IN_COPYRIGHT

This document was created from content at the Biodiversity Heritage Library, the world's largest open access digital library for biodiversity literature and archives. Visit BHL at https://www.biodiversitylibrary.org. 